NAS.NRC PUb 655 Ref.

\title{
Radioactive Waste Disposal into
}

\section{Atlantic and Gulf Coastal Waters}

\section{TD \\ $8 / 2$ \\ . N28 \\ 1959

NATIONAL ACADEMY OF SCIENCES -

NATIONAL RESEARCH COUNCIL 
The Committee on Oceanography was organized in 1957 within the Division of Earth Sciences of the National Academy of SciencesNational Research Council. Its activities have been jointly sponsored by the Atomic Energy Commission, the Bureau of Commercial Fisheries, the National Science Foundation and the Office of Naval Research. The Committee's objectives are to assist in the development of the marine sciences, to encourage basic research and to advise the government agencies on various oceanographic problems.

The map on the front cover is a portion of a chart originally published in Pefer Goos' De Zee Atlas in 1667. We are grateful to the American Geographic Society for loan of the original map and permission to reprint it here. 


\section{Radioactive Waste Disposal}

into
Atlantic and Gulf
Coastal Waters

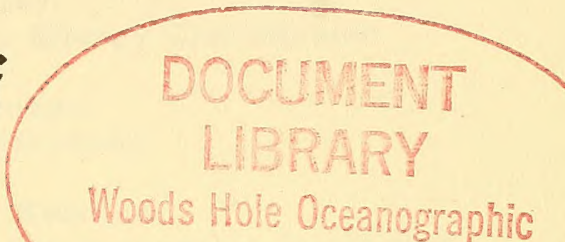

A Report from a Working Group of the Committee on Oceanography of the National Academy of

Sciences-National Research Council.

Publication 655

National Academy of Sciences-National Research Council Washington, D.C. 
Library of Congress catalog card number: 59-60046 
Dayton E. Carritt, Chairman,

The Johns Hopkins University

Dean F. Bumpus

Woods Hole Oceanographic Institution

James H. Carpenter

The Johns Hopkins University

Walter A. Chipman

U. S. Fish and Wildlife Service
John H. Harley

U. S. Atomic Energy Commission

Bruce C. Heezen

Columbia University

Bostwick H. Ketchum

Woods Hole Oceanographic Institution

Robert O. Reid

A. and M. College of Texas

\section{Consultants}

Howard Eckles

Department of the Interior
Arnold Joseph

U. S. Atomic Energy Commission 



\section{TABLE OF CONTENTS}

Page

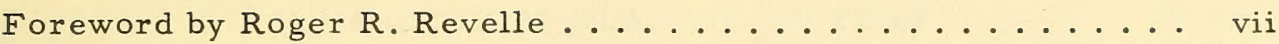

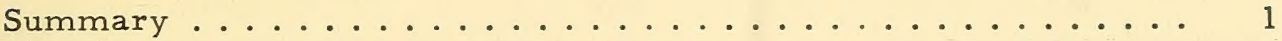

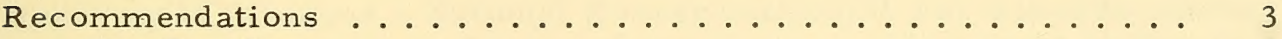

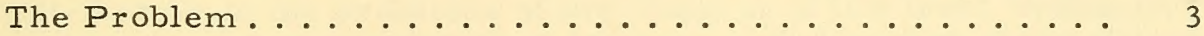

Present Sea Disposal Practices .................... 4

Low Level Wastes Generated Within AEC Facilities . . . . . . 6

Low Level Wastes Generated Within Government Operations

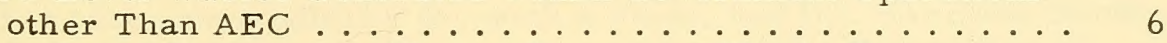

Low Level Radioactive Wastes Generated Within Private

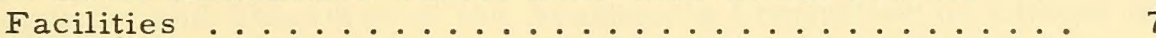

Estimate of the Fraction of the Production of Oak Ridge National Laboratories Shipped to Other Than Atomic

Energy Commission Operations, That Became Wastes for

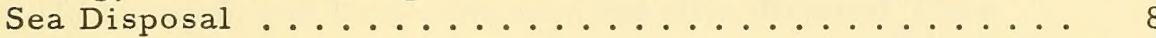

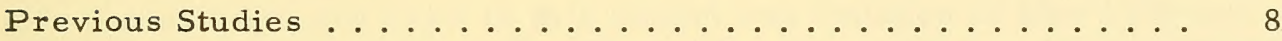

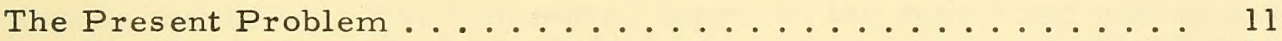

The Basis for Judgment ..................... 11

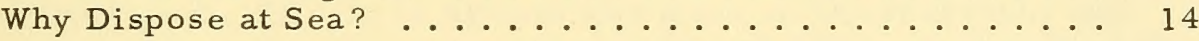

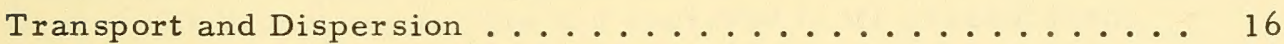

Movement of Bottom Sediment .............. 16

Near-bottom Water Circulation ................ 16

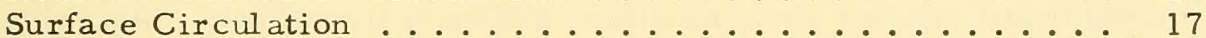

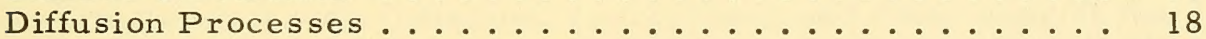

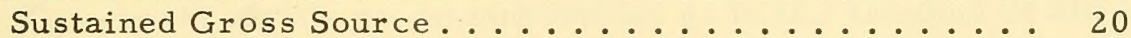

Instantaneous Source ...................... 21

Continuous Sources at Uniform Leaching Rate...... 23

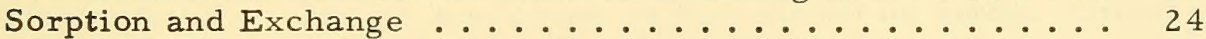

Permissible Concentrations of Radioisotopes in Sea Water

and Uptake by Marine Organisms ............. 26

Possible Conflict with Other Interests ........... 27

Commercial Fisheries ................ 27

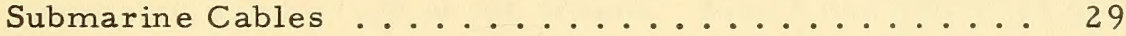

Maximum Rate of Disposal .................... 30

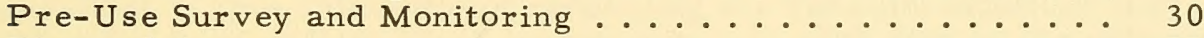

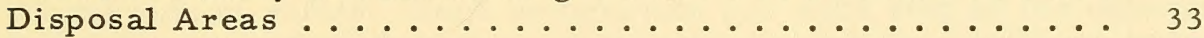

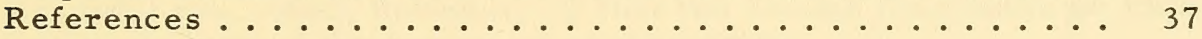





\section{FOREWORD}

\section{RADIOACTIVE WASTE DISPOSAL INTO ATLANTIC AND GULF COASTAL WATERS}

In January 1958, the Committee on Oceanography of the National Academy of Sciences - National Research Council was asked to conduct a detailed study of the problems of the disposal of low level radioactive wastes into the Atlantic and Gulf of Mexico coastal waters of the United States. This request was made jointly by the three government sponsors of the Committee: The Bureau of Commercial Fisheries, the U. S. Atomic Energy Commission, and the Office of Naval Research.* The Committee agreed to take responsibility for such a study, and Dr. Harrison Brown, Committee Chairman, asked me, as a member of the Committee on Oceanography and Chairman of the Academy's Committee on Effects of Atomic Radiation on Oceanography and Fisheries, to call together a special working group. This group was asked to consider the levels of radioactive wastes that can be disposed of safely, the kinds of packaging that should be used, and to recommend specific disposal sites.

A preliminary draft of this report was finished in May 1958 and discussed in detail before a meeting of the Committee on Oceanography shortly thereafter. The Committee approved the report and authorized its reproduction in mimeograph form prior to a similar review by the Committee on the Effects of Atomic Radiation on Oceanography and Fisheries. The latter Committee met in March 1959. At that time the report was brought up to date and approved in its present form.

In its study, the group has taken into account the effects of local oceanographic conditions, possible health hazards and the importance of non-interference with fisheries, recreational and other uses of the oceans. The report makes recommendations as to the amounts of different radioactive is otopes that can be disposed of safely in any one area. Twenty-eight possible disposal sites are listed. Before any one of these is finally selected, a pre-use survey should be made. The area should be monitored periodically after disposal begins.

The working group has attempted to make its recommendations as precise as possible within the limits of our present knowledge of the physics, chemistry, and biology of the oceans. Where uncertainties exist because of inadequate knowledge a conservative position has been chosen-that is, the calculations underlying the recommendations may err on the side of safety. Each assumption and each step in the calculations is fully described, however, so that the reader may make an independent evaluation of the degree of conservatism.

*The National Science Foundation has since become one of the sponsors of the Committee. 
Publication of this report is made possible through the cooperation of the National Academy of Sciences - National Research Council, Earth Sciences Division, Committee on Waste Disposal, Advisory to the U. S. Atomic Energy Commission. For the results of other NAS - NRC studies pertaining to the disposal of radioactive wastes, the reader is referred to "The Disposal of Radioactive Wastes on Land" NAS - NRC Pub. 519, April 1957, and "Thermal Considerations of Deep Disposal of Radioactive Wastes", a special report by Dr. Francis Birch, NAS NRC Pub. 588, September 1958.

Reports are also in progress on the disposal of low-level wastes into Pacific coastal waters and on radioactive waste disposal from nuclear-powered ships.

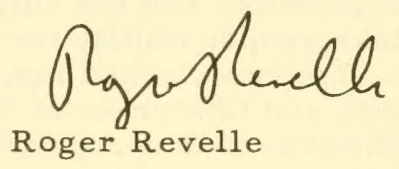

Scripps Institution of Oceanography La Jolla, California May 1959 


\section{RADIOACTIVE WASTE DISPOSAL INTO ATLANTIC AND GULF COASTAL WATERS}

\section{SUMMARY}

A study has been made of the feasibility of using selected areas in the Atlantic and Gulf of Mexico coastal waters of the United States as receiving grounds for the disposal of packaged, low level radioactive wastes.

The primary objective of the study has been to provide an estimate of the rate of return of radioactive substances to man, arising from stated rates of disposal into the coastal areas. The limiting rate of disposal has been taken as that which through a combination of physical and biological processes will return the radioactivity to man at a rate equal to the maximum permissible rate of ingestion of a given radionuclide in drinking water.

These rates were based on the occupational MPC's (maximum permissible concentration) given in Handbook 52 (3). The MPC's for the general population according to recent information should be lowered by a factor of 10 . The revised MPC's of some isotopes may be reduced even further. It is believed, however, that the conservative assumptions contained in this report offset the effects of these reductions in MPC values.

The present practice of using 55 gallon steel drums as disposal canisters containing the waste mixed with concrete is estimated to provide containment of approximately 10 years, during which time radioactive decay will have destroyed all radioisotopes (based upon Oak Ridge National Laboratories current rate of production and shipment) to below hazardous levels, with the exception of $\mathrm{Sr} 90, \mathrm{Cs} 137$, and possibly Co 60 .

Coastal circulation is not known in sufficient detail to provide quantitative estimates of the rate of transport of a contaminant out of any of the areas selected as possible disposal sites. These estimates can be made only after detailed circulation studies have been completed. Especially lacking is knowledge of the circulation of bottom waters. Nevertheless, several areas stand out as being probably unsuited as disposal sites. They are the coastal estuaries and bays, and the regions immediately seaward of these areas. Shoreward transport along the bottom in these regions would tend to intensify the rate of return of a contaminant to man. Also, a region southeast of Long Island, extending out to approximately 50 fathoms, appears to have restricted bottom 
circulation during the summer months and therefore might accumulate larger quantities of contaminant than other coastal areas.

A theoretical study of the dilution of contaminant by turbulent mixing processes has been made. The results of the study provide the means of evaluating the effects of changing environmental parameters and of various disposal methods on the dilution of a contaminant. Because of the assumptions made all estimates of concentration at a given distance and time are probably higher by at least a factor of ten than would actually exist in practice. Even with these conservative assumptions calculations show that given a rate of disposal of 100 curies per year of uncontained waste into water 30 meters deep with a current of 5 miles per day, the maximum concentration of waste which will appear one kilometer (approximately 5/8 miles) from the disposal site will be $2 \times 10^{-7} \mu \mathrm{c} / \mathrm{ml}$, a concentration that is lower than the maximum permissible concentration of $\mathrm{Sr} 90$ in drinking water. Sr 90 has the lowest MPC value of all radioisotopes listed. In addition, the relationships between both relative concentration and time after release and distance from the disposal site, under the unlikely condition that no current will aid in diffusive mixing, have been developed.

In arriving at recommended disposal rates the interaction of a contaminant with suspended solids and bottom sediments has been neglected. It was found impossible to make a quantitative estimate of the magnitude of this reaction. Neglecting this factor puts a certain factor of safety in the recommendations, as sorption onto bottom sediments within the disposal area will provide additional containment, thus allowing for further destruction of the contaminant by radioactive decay. In the case of disposal into areas productive in commercially important shellfish (oysters, clams, etc.) the sorption onto bottom deposits may become a potential hazard rather than a safety factor. This situation has been eliminated by selecting areas in which no shell fisheries occur.

The return of radioactive wastes to man by ingestion of contaminated marine food products is considered to be the most likely potential source of hazard that could result from disposal into coastal waters. An estimate has been made of the maximum permissible concentration of each of several radioisotopes in sea water, below which contamination of marine food products will not lead to greater than allowable intake by humans whose sole source of protein is fish. This estimate was derived from the maximum permissible concentration of the isotopes in drinking water, from which was computed the maximum weekly intake of each of the isotopes; the weekly ingestion rate of fish, taken as $1.5 \mathrm{~kg}$, a value that is high compared with the per capita value for this country but has been taken on the as sumption that some individuals obtain all of their protein from fish; and the extent to which marine organisms can concentrate the various isotopes within themselves above the level in their environment. The most hazardous isotope in the list is $\mathrm{Sr} 90$, for which the maximum permissible concentration in sea water is $8 \times 10^{-7} \mu \mathrm{c} / \mathrm{ml}$, which by coincidence is identical with the MPC value for drinking water. 
Suggested disposal areas have been chosen in an attempt to minimize conflict with submarine cable operation, as well as the purely mechanical problems connected with fisheries activities.

\section{RECOMMENDATIONS}

The panel is of the opinion that certain Atlantic and Gulf of Mexico coastal areas can be used as receiving waters for the controlled disposal of packaged, low level, radioactive wastes.

Twenty-eight possible locations have been selected (figure 7, p. 34) that could, on the basis of presently available information, be used without limiting our other uses of coastal waters. The actual choice of disposal areas should be undertaken within the following limitations:

1. Prior to start of disposal operations a survey of an area must be made to determine details of local circulation and an inventory of the biota, especially of bottom-living organisms.

2. The total quantity of activity that is deposited into any one disposal area in any one year should be limited to 250 curies of Sr 90 or the equivalent of other isotopes. For the equivalent amounts of other isotopes see Table II and the accompanying discussion on page 13.

3. The total quantity of activity that is deposited in any one area during any given month should be limited to 100 curies of Sr 90 or the equivalent of other isotopes. miles.

4. Adjacent disposal areas should be separated by at least 75

5. No 300 mile section of coast line should contain more than three disposal areas unless predominant currents, both bottom and surface, indicate that no exchange between areas is posible.

6. The waste container should be of such construction that no part of it or its contents will float to the surface should the container be broken. The practice of using steel drums as containers is recommended as giving appreciable holding time in the disposal area.

7. Periodically during use, the area should be monitored to provide a measure of the spread of radioactivity throughout the region including both the biota and the bottom sediments, and to note changes that might be caused by disposal operations. The results of this monitoring may indicate that certain of the above as sumptions should be changed.

\section{THE PROBLEM}

The U.S. Atomic Energy Commission has asked the Committee on Oceanography of the National Academy of Sciences - National 
Research Council to study the feasibility of disposing of low level, packaged, radioactive wastes into the on-shore waters of the Atlantic and Gulf of Mexico coasts of the United States. The areas of special interest are closer to shore than the present designated areas now 100 and more miles out.

The objectives of the study are to recommend locations that can be used safely as disposal areas, together with the limitations on quantity and kinds of radioactive materials, rates of disposal, and other pertinent factors necessary to keep the concentration of radioactive substances within permissible levels.

Of special interest is the use of near-shore regions as disposal areas for the low level radioactive wastes generated in university and industrial laboratories, hospitals, and research institutions licensed by AEC to use relatively small quantities of radioactive materials.

We emphasize here the term low level wastes. These are broadly classified as wastes containing up to the equivalent of millicurie quantities of activity per gallon. They are distinct from high level wastes, such as those obtained from the processing of spent reactor fuels which may contain hundreds of curies per gallon. The present study is not concerned with the disposal of high level wastes.

\section{PRESENT SEA DISPOSAL PRACTICES}

With the increasing quantities of radioactive materials that have been used in peacetime applications by both AEC and non-AEC institutions there has been a corresponding increase in the quantities of low level wastes that have no further usefulness, but because they do represent a potential health hazard cannot be disposed of by conventional methods (municipal incinerators, sanitary dumps, etc.). In the past, much of this waste material has been packaged and dumped into designated areas approximately 200 miles off the Atlantic Coast in approximately 1000 fathoms of water. Much of the material has been carried to the disposal areas by naval vessels during scheduled disposal of non-radioactive wastes. In addition, civilian waste disposal concerns, licensed by the AEC, have dumped small quantities of low level wastes into coastal waters in areas normally used as receiving areas for nonradioactive wastes. Recently AEC received several new requests for the licensing of civilian marine disposal concerns.

Table I and figure 1 summarize the sea disposal operations that have been conducted along the Atlantic Coast from 1951 to 1958. (1) It should be emphasized that the quantities of activity listed were not measured at the time of disposal to the sea. At best, they were measured at the time of packaging of the wastes, and frequently the values reported are estimates made by the users of the material who listed the total amount of activity shipped to them, with no allowance made for losses during use and for radioactive decay. The quantities listed are therefore, unquestionably, larger than the quantities actually deposited in the disposal areas. 
TABLE I

PAST AND PROJECTED AMOUNTS OF RADIOACTIVE MATERIALS DISPOSED IN ATLANTIC OCEAN

\begin{tabular}{|c|c|c|c|}
\hline \multirow[b]{2}{*}{ Origin } & \multicolumn{2}{|c|}{ Quantity (curies) } & \\
\hline & $1951-1957$ & $\begin{array}{l}\text { Estimated } \\
1958-1963\end{array}$ & Location (Fig. 1) \\
\hline
\end{tabular}

AEC wastes (U. S. Navy Disposal)

5,370

$a, b$

Government agencies, non-AEC
(U.S. Navy and Coast Guard Disposal)
4.3
531.9
b, c

University and industrial labs.

(Private Disposal)

$10+$

$25+$

$d, e, f$ and unlettered

Data from reference (1)

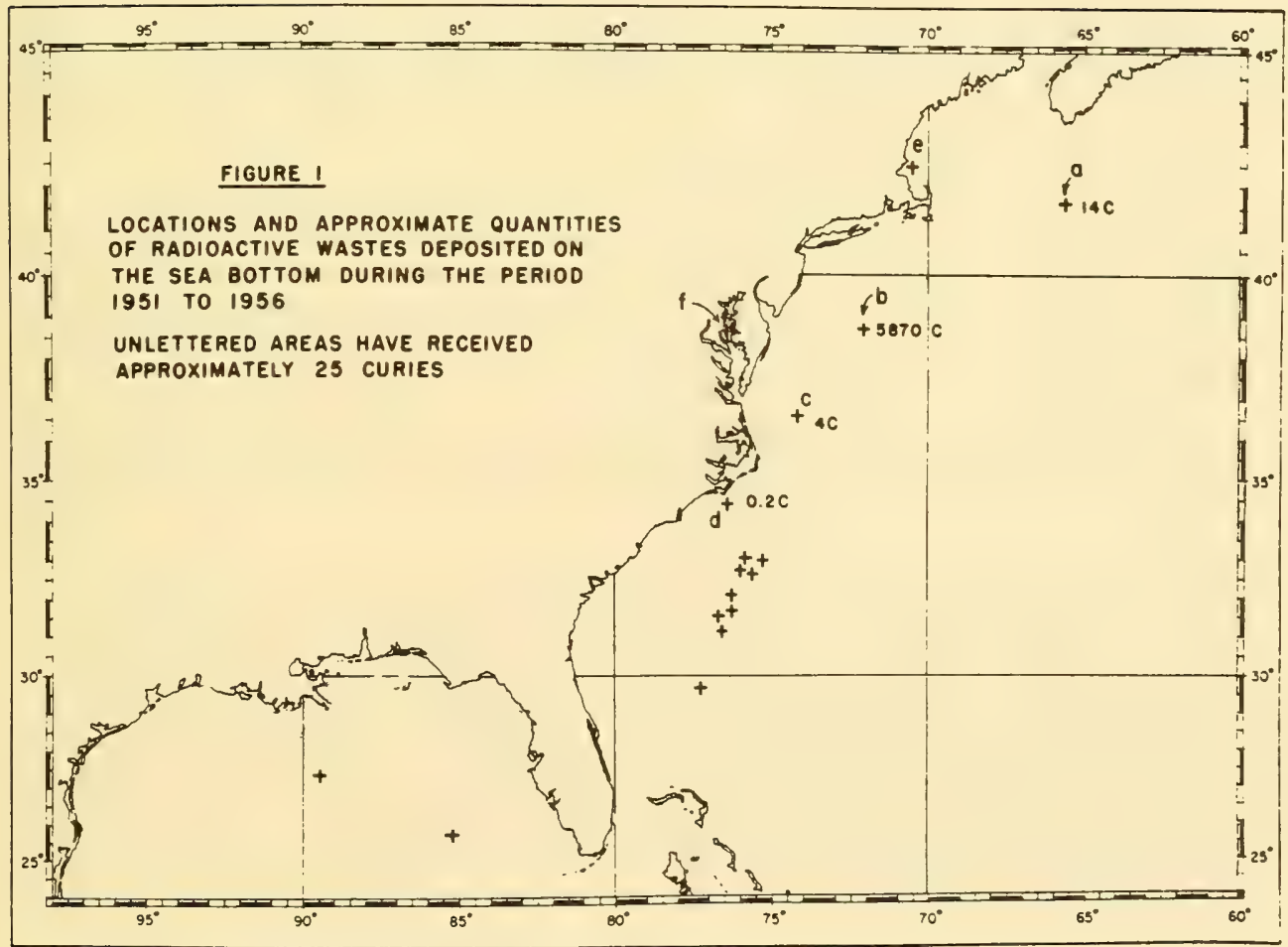


These disposal operations can be divided into three broad subdivisions, using the immediate source of the wastes as a criterion. They are:

1. Low level wastes generated within AEC facilities.

These constitute, by far, the largest quantities of radioactive materials that have been deposited in the Atlantic disposal areas. Since 1951,5870 curies of a variety of isotopes contained in 8432 fifty-five gallon drums have been disposed of. A rather insignificant fraction of this total was deposited in the designated area approximately 200 miles due east of Cape Cod, area a, figure 1. Most of it has been added to the disposal area approximately 200 miles east of Cape May (Delaware Bay), area $\underline{b}$, figure 1 .

The AEC has described the general nature of these wastes as follows (1):

"AEC wastes which are dumped at sea are heterogeneous in character and as a rule contain quantities of activity normally associated with laboratory experimentation and with decontamination operations. For the most part, they consist of solid materials such as paper wipes, rags, mops, ashes, animal carcasses and contaminated laboratory paraphernalia. Some liquids containing radioactivity in the concentration range of microcuries per liter have been incorporated in cement mixtures or with chemical gelling materials prior to packaging and dumping. Because the wastes and their contaminating radioisotopes are heterogeneous in character, it is difficult to determine accurately the total quantities of radioactivity involved."

Most of these wastes have been packaged in fifty-five gallon drums with added concrete to insure proper bulk density. The AEC has set specifications (1) (2) for the packaging and handling of contaminated scrap.

2. Low level wastes generated within government operations other than AEC.

Four agencies (the National Bureau of Standards, the Naval Ordinance Laboratory, the Naval Research Laboratory, and the National Institutes of Health) all in the Washington, D.C. area, have since 1955 generated approximately four curies of heterogeneous wastes that have been deposited in a designated disposal area, approximately 75 miles east southeast of Cape Henry (Cheasapeake Bay), by the U.S. Coast Guard. This is area c, figure 1. The U.S. Fish and Wildlife Service, Beaufort, N.C., has disposed of less than 0.2 of a curie of heterogeneous wastes, in area d, figure 1, approximately 8 miles off-shore from Beaufort, North Carolina. 
3. Low level radioactive wastes generated within private facilities.

Several industrial concerns and research laboratories licensed by AEC to use radioactive materials have either conducted their uwn waste disposal operations or have contracted with licensed marine disposal companies to have the wastes carried to sea. The areas in which low level radioactive wastes have been dumped at sea by these operations are the unlettered areas in figure 1. Approximately 25 curies have been disposed of through these channels, most of it several hundred miles off shore.

In all, something less than 6000 curies were added to the water off the Atlantic coast of the U.S. between 1951 and 1958. The exact composition of this waste material is uncertain; that is, it is impossible to determine the quantities of various radioisotopes, and in many cases the total activity associated with a disposal container is uncertain. By far the greatest bulk of this material has been deposited into water 1000 fathoms or more deep, and in containers that will provide some factor of safety to the environment, in that at least a part of the wastes will have disappeared by natural radioactive decay before being released to the sea.

A survey of the area that has received most of the wastes, area $\underline{b}$, figure 1, was made by the Chesapeake Bay Institute of The Johns Hopkins University, and the U.S. Coast and Geodetic Survey. The activity, beta and gamma counting, of samples of bottom sediments taken within the disposal area was compared to the analysis of samples taken outside of the area. No difference could be found. Comments on survey methods will be made in a later section.

The quantity of low level radioactive wastes that will, under existing operational procedures, find its way into the Atlantic coastal waters is increasing. The off-shore, deep water disposal areas appear to be adequate to handle projected quantities of these wastes without limiting our other uses of these waters. Of immediate concern to the $A E C$ is the increase in the quantities of radioactive materials used by non-governmental agencies and the increase in the numbers of commercial marine disposal concerns who are seeking licenses to handle and dispose of the low level radioactive wastes into shallow coastal areas.

In general, marine disposal concerns are at present not equipped to carry the wastes several hundred miles to sea, at least not without a considerable increase in the cost of the service. The disposal concerns would like to deposit these wastes in existing or newly designated disposal areas in the relatively shallow coastal waters up to approximately fifty miles from shore. One concern has, with AEC permission, disposed of limited quantities of packaged low level wastes in 50 fathoms of water, some twelve to fifteen miles from the coast, area $\underline{e}$, figure 1. 
4. Estimate of the fraction of the production of Oak Ridge National Laboratories shipped to other than AEC operations, that became wastes for sea disposal.

During the period January 1956 to September 1957, ORNL shipped approximately 50,000 curies, measured at the time of shipment, for use by non-AEC facilities. Of this total, approximately 28,759 curies were isotopes with short half lives, while isotopes of strontium, cobalt, cesium, iron, and zinc amounted to 21,14l curies, of which 21,020 were shipped as "sealed sources". Assuming that sealed sources (cobalt bars, for example, used as radiation sources) will not find their way into commercial disposal routes when their initial usefulness has passed, 121 curies of long-lived isotopes appear as the potential supply that might have arrived at dockside for disposal at sea. During the same period, an estimated 25 curies (composition doubtful) was actually disposed of at sea.

If the assumption concerning the fate of "sealed sources" is correct and if the estimate of 25 curies disposed of at sea is correct, then approximately $20 \%$ of the ORNL shipments of "hazardous isotopes" to non-AEC users will eventually appear as wastes for sea disposal.

\section{PREVIOUS STUDIES}

Several studies have been made since 1950 that are either directly or indirectly concerned with the disposal of radioactive substances into the sea. The first of these, published as U.S. Bureau of Standards Handbook 52 (3) lists the quantities of each of a number of radioisotopes that can be retained safely in the body, as well as the concentration of each isotope that can be tolerated in drinking water and in air. The maximum permissible body burden, drinking water and air concentrations are considered to be the levels below which no readily detectable biological damage will occur in man under conditions of continual exposure at those levels.

Although the recommendations contained in Handbook 52 were based upon the best biological and radiological evidence available, the authors note that in several cases the evidence available to them was scant and that the maximum permissible concentration levels should be revised as new evidence becomes available. In this connection Looney (9) suggested that the accepted level for radium, which forms the basis (in part) for the calculation of the permissible levels of other isotopes, is too high and recommends that the radium level be lowered until more information becomes available on the effects of radium in man over a normal lifetime.

In calculations made later in this report, the recommended maximum permissible levels in Handbook 52 have been used. We realize that man does not drink seawater; however, the Handbook 52 values give a basis for estimating the maximum permissible rate of ingestion of radionuclides that may be contained in marine food products. 
In 1954 a study was made by the sub-committee on Waste Disposal and Decontamination of the National Committee on Radiation Protection, of the problems connected with the disposal of radioactive materials in the ocean. This study was published as Handbook 58 of the National Bureau of Standards (4). Although Handbook 58 does not make specific recommendations with regard to disposal site locations, rates of disposal, etc., it does recommend that all radioactive wastes that are to be disposed of into the sea be packaged and that disposal be into water at least 1000 fathoms deep. These two recommendations form the basis for present AEC sea disposal regulations. In addition, Handbook 58 enumerates the physical, chemical, and biological factors thought to be important in regulating the dispersal of a contaminant throughout the oceans. However, because of lack of quantitative information. no attempt was made to combine the various factors to obtain an estimate of the level of contamination of the ocean and marine food products associated with stated disposal practices.

In 1956 the National Academy of Sciences - National Research Council organized six committees to study various aspects of the biological effects of atomic radiation. The report of one of these Committees, the Committee on the Effects of Atomic Radiation on Oceanography and Fisheries, was published in 1957 as Publication 551 of the National Academy of Sciences - National Research Council (5).

Publication 551 gives a detailed account of the state of knowledge of the physical, chemical, biological and geological factors involved in the interaction of radioactive wastes, especially fission product elements, with the marine environment. While much of this study is concerned with the deep oceans, and the massive quantities of materials that will be produced as a result of nuclear power production, it is, nevertheless, a useful guide in the attempted solution of all problems concerned with radioactive wastes and the marine environment.

Following the 1956 meetings of the Committee on the Effects of Atomic Radiation on Oceanography and Fisheries, but before Publication 551 was completed, a meeting of several scientists from the United States and the United Kingdom was held, at which there was a liberal exchange of information concerning the problems of the disposal of radioactive wastes in the oceans. At that meeting it was learned that the British Atomic Energy Authority plant at Windscale, on the Irish Sea, was discharging low level liquid wastes through a three mile long pipeline, directly into the Irish Sea, with authorization to discharge at the rate of 1000 curies per month. The basis for the authorization was the results of a series of studies giving: (1) the detailed circulation of the Irish Sea area immediately seaward from the Windscale plant; (2) the uptake of activity by migratory fish that pass through the area; (3) the contamination of an edible seaweed that is harvested in an adjoining area, estimated from the circulation study and uptake experiments; and (4) the level of contamination of local beaches, estimated from the circulation study. 
It is now believed that as a result of monitoring studies made during the build-up to the 1000 curie per month discharge level, and a reassessment of the "safety factors" that were included in the original studies and recommendations, authorization has been given to discharge at the rate of 10,000 curies per month.

A summary of the discussions at the meeting has been distributed under the title "Report of a Meeting of United Kingdom and United States Scientists on Biological Effects of Radiation in Oceanography and Fisheries," National Academy of Sciences - National Research Council, October 31,1956 (6). A portion of that report is quoted below, as it has direct bearing on the studies of the present committee.

\section{Disposal into Coastal Waters}

Maximum quantities and rates of disposal of radioactive substances into coastal waters are set, in all cases, by two considerations. The first is the transfer of these substances back to man and his surroundings. The second is the effect upon the marine resources and environment.

\section{Bulk Liquids}

In coastal waters it will, in general, be possible, in proper circumstances, to dispose of wastes in dilute liquid form, but the permissible quantities of radioactivity in such wastes may be expected to vary considerably from one area to another because of the diverse nature of coastal situations.

A careful study is required to determine the safe quantity of each isotope in each situation, including the details of the physical, chemical, and biological factors, and the habits of the human population potentially affected.

Continuing studies are required at each disposal locality to insure safety, to determine ultimate steady state conditions, and to detect possible long term variations arising from variability of the environment.

Such investigations have been carried out over a number of years in the Irish Sea and the results indicate that fission products can be safely released in that area at an average rate of several hundred curies a day; it appears likely, therefore, that similar quantities of waste could be safely liberated in some other areas.

In selecting locations for nuclear installations the waste disposal problems should be taken into account. Because of the additive effects of wastes independently discharged into the same water mass, the proximity of other facilities is an important consideration. 
Packaged Wastes

Packaged liquids and sludges in containers which can rupture and thus liberate their contents to the sea, and solid materials of density greater than sea water may also be safely disposed of in coastal waters if proper precautions are observed. The amount of activity which is dissolved in the sea water, or taken up by organisms, from such materials is subject to the same limitations as for bulk liquid wastes.

Precautions must be taken to guard against recovery by fishing or salvage operations, or transport to areas where the material could constitute a hazard. Disposal areas for such wastes should be in designated locations, and all disposal should be adequately recorded and controlled.

\section{THE PRESENT PROBLEM}

The basis for judgment.

The request from the Atomic Energy Commission asks essentially for a differentiation between safe and unsafe procedures related to the dumping of radioactivity into coastal waters.

The determination of where safe procedures end and unsafe procedures begin involves an evaluation of information in two very different fields of science. The first is radiation biology, a field that can supply information concerning tolerance limits for the quantities of radioactive materials that man can have either in his immediate environment or within himself, without regard for how it gets there. The second science field is oceanography, which can supply a description of the processes that can bring radioactive substances from a marine disposal area back to man.

We emphasize here that the very nature of the primary information upon which our evaluation is based makes the division between safe and unsafe disposal procedures a rather broad region rather than a sharp dividing line. Because of this we have, with purpose, adopted a conservative attitude in our integration of the many pieces of information that make up our conclusions.

Radioactive substances are a potential hazard to man, (1) because of radiation received from the immediate environment (external emitters), and (2) because of radiation received by substances taken into the body by ingestion, inhalation, or absorption through the skin (internal emitters). In both cases the potential hazards may do damage to the individual so as to reduce the life span, impair the functioning of parts of the body, etc., i.e. pathological damage, or to increase the mutation rate which will alter the inherited characteristics in future generations, i.e. genetic damage. 
Our present state of knowledge with regard to the pathological effects of radiation is given in detail in NAS-NRC Publication 452 (7). A summary report of the National Academy of Sciences - National Research Council Committee on the Genetic Effects of Atomic Radiation was published in 1956 (8).

The separation of safe from hazardous sea disposal procedures must be made, first of all, on the basis of potential hazard to man through his normal utilization of the sea, and secondly, on the possibility of injurious effect produced in the marine environment itself.

Our assessment of the quantities and the rates of disposal of low level radioactive wastes into in-shore water that will create a potential hazard to man, through his uses of the sea and marine products, developed from consideration of the natural processes occurring in the marine environment that could bring the radioactive wastes back to man from suggested disposal sites. We have recognized two mechanisms that appear to be the most likely avenues through which this could occur. They are: (1) transport of the radioactive wastes from the disposal sites to the immediate shoreline, thereby creating a potential hazard in man's recreational uses of the coast, and (2) uptake of the radioactive waste components by one or more of the trophic levels in the marine biota with return to man in commercially important fish and shellfish.

We would emphasize at this point that in all cases our separation of hazardous from non-hazardous procedures, so far as man's tolerance for radiation is concerned, is based upon the Handbook 52 values for maximum permissible amounts of radioisotopes in the total body and maximum permissible concentrations in water. The latter are for drinking water or for submersion in contaminated fluids. These values consider only pathological effects. No evaluation of possible genetic damage was attempted when Handbook 52 values were compiled. The conclusions in this report, then, may need revision if Handbook 52 maximum permissible levels are drastically altered, or when some of the uncertainties introduced by lack of information in our evaluation of the oceanographic factors become better known. However, since Handbook 52 values are thought to be conservative and since our analysis of the oceanographic factors presents a conservative estimate of the behavior of the environment, as will be described below, we believe disposal practices based upon our recommendations have little likelihood of producing a hazard to man's present uses of the coastal waters.

In the reports of quantities of radioactive substances already disposed of at sea one usually finds only the number of curies recorded. Only infrequently are the isotopes listed. Although this is unavoidable in many cases, a knowledge of the curie content of a disposal container only partially defines the potential hazard of the material. The extreme variability in the maximum permissible concentrations of various isotopes in drinking water (3), for example, $2 \times 10^{-1}$ and $8 \times 10^{-7} \mu \mathrm{c} / \mathrm{cc}$ for tritium and strontium 90 respectively, emphasizes this point. 
In the discussions which follow we will be concerned primarily with strontium 90. The hazard of other isotopes, relative to strontium 90, insofar as uptake by marine organisms and return to man in marine food products is concerned, will be given by the ratio of the permissible sea water concentration of an isotope to that of strontium 90. Table II lists the number of curies of each of a group of selected isotopes, equivalent to 250 curies of strontium 90, the latter value being the suggested maximum yearly rate of disposal of strontium 90 into any one disposal area. Also shown are the quantities of each of the isotopes that would decay to 250 equivalent curies following containment of one month and of one year.

The significance of the quantities of isotopes relative to strontium90 is apparent when considering the practical problem of the disposal of packages containing a mixture of isotopes. Assume, for example, that packages containing waste of the following composition have been added

TABLE II

QUANTITIES OF SELECTED RADIOISOTOPES EQUIVALENT ${ }^{1}$ TO 250 CURIES OF STRONTIUM 90, SHOWING THE INITIAL QUANTITIES THAT WILL DECAY TO 250 EQUIVALENT CURIES ALLOWING ONE MONTH AND ONE YEAR CONTAIN. MENT

\begin{tabular}{lccc} 
Isotope & \multicolumn{3}{c}{ Curies } \\
\hline Na 24 & $5.0 \times 10^{7}$ & 1 mo. containment & 1 yr. containment \\
P 31 & 15.5 & $10^{24}$ & $10^{183}$ \\
S 35 & $3.1 \times 10^{6}$ & 68.6 & $1.1 \times 10^{9}$ \\
K 42 & $3.1 \times 10^{6}$ & $3.9 \times 10^{6}$ & $5.6 \times 10^{7}$ \\
Co 45 & $1.6 \times 10^{5}$ & $10^{14}$ & $10^{226}$ \\
Fe 59 & $1.2 \times 10^{3}$ & $1.8 \times 10^{5}$ & $7.5 \times 10^{5}$ \\
Co 60 & $6.2 \times 10^{3}$ & $1.9 \times 10^{3}$ & $3.3 \times 10^{5}$ \\
Cu 64 & $5.0 \times 10^{4}$ & $6.3 \times 10^{3}$ & $7.0 \times 10^{3}$ \\
Zn 65 & $1.4 \times 10^{4}$ & $10^{21}$ & $10^{201}$ \\
Sr 90 & 250 & $1.5 \times 10^{4}$ & $3.8 \times 10^{4}$ \\
I 131 & $9.3 \times 10^{2}$ & 250 & 250 \\
Cs 137 & $9.3 \times 10^{4}$ & $1.2 \times 10^{4}$ & $10^{16}$ \\
\hline
\end{tabular}

IEquival ence based upon ratios of Permissible Sea Water Concentrations. 
to a disposal area; 525 curies of $\mathrm{Na}-24 ; 1000$ curies of $\mathrm{Ca}-45 ; 100$ curies of $\mathrm{Fe}-59 ; 100$ curies of $\mathrm{Co}-60 ; 120$ curies of $\mathrm{Sr}-90$; and 1000 curies of Cs-137. The total number of curies amounts to 2,845 well over the suggested yearly limit of 250 curies of $\mathrm{Sr}-90$. Obviously, the relative hazard to man, considered in the route that might return the waste to him from the disposal area through marine food products, will be less for the mixture than for strontium-90. If the quantities of each of the isotopes above are multiplied by the ratio of the maximum permissible sea water concentration of strontium-90 to that of the isotope, the sum of results assuming no containment is approximately 148 curies. This figure, which is a more realistic measure of the potential hazard of the waste than the 2,845 curies, includes the effect of MPC values for each isotope and the concentration factors from sea water to marine food products.

\section{Why dispose at sea?}

There are two ways of handling radioactive materials to prevent them from becoming a hazard to man. One is by containment, which has as its objective the retention of the material in such a manner that it does not get into the human environment, at least until natural radioactive decay has reduced the quantity of material to below permissible levels. The other is by dispersal, which has as its objective the dilution of the waste to below permissible levels before it becomes a part of the immediate human environment.

Within limits, procedures can be established so that disposal into coastal waters can take advantage of some of the desirable features of both methods of handling the wastes. The advantage of containment can be achieved by proper canister design. Presently used canisters are reclaimed 55 gallon steel drums which have an expected life, so far as corrosion by sea water is concerned, of approximately ten years (10).

The factor of safety introduced by ten year containment is shown in Table III, in which the percents of the initial activity remaining after ten years and the maximum permissible concentrations for drinking water are listed for a group of isotopes including high yield, long-lived fission products and the isotopes that are shipped from Oak Ridge National Laboratories to licensed users.

Two features of Table III should be emphasized. First, isotopes having long half life, that is, relatively large amounts remaining after ten years, and low MPC values are those that may produce the greatest potential hazard to man. Second, the MPC values are drinking water values and we are concerned here with sea water. Although not directly applicable to the present problem, these MPC values will be used later in modified form.

The practice of mixing contaminated materials into concrete which is then cast into the steel drum, provides for containment 
TABLE III

PERCENTAGES OF INITIAL ACTIVITY REMAINING AFTER TEN YEAR CONTAINMENT AND MAXIMUM PERMISSIBLE CONCENTRATIONS FOR DRINKING WATER, FOR SELECTED FISSION PRODUCT ELEMENTS AND ORNL ISOTOPES

\begin{tabular}{|c|c|c|c|c|c|}
\hline Isotope & $\begin{array}{c}\text { Percent after } \\
10 \text { years }\end{array}$ & $\begin{array}{l}\operatorname{MPC}(3) \\
(\mu \mathrm{c} / \mathrm{ml})\end{array}$ & Isotope & $\begin{array}{c}\text { Percent after } \\
10 \text { years }\end{array}$ & $\begin{array}{l}\operatorname{MPC}(3) \\
(\mu \mathrm{c} / \mathrm{ml})\end{array}$ \\
\hline $\mathrm{H}^{3}$ & 57.5 & 0.2 & $Z_{n} 65$ & $4.2 \times 10^{-3}$ & $6 \times 10^{-2}$ \\
\hline$C^{14}$ & 99.9 & $3 \times 10^{-3}$ & $\mathrm{Sr}^{89}$ & $10^{-18}$ & $7 \times 10^{-5}$ \\
\hline $\mathrm{Na}^{24}$ & $10^{-1768}$ & $8 \times 10^{-3}$ & $\mathrm{Sr}^{90}$ & 75.8 & $8 \times 10^{-7}$ \\
\hline$p^{32}$ & $10^{-75}$ & $2 \times 10^{-4}$ & $Y^{91}$ & $10^{-17}$ & 0.2 \\
\hline $\mathrm{S}^{35}$ & $10^{-8}$ & $5 \times 10^{-3}$ & $\mathrm{Zr}^{95}$ & $10^{-17}$ & \\
\hline$K^{42}$ & $10^{-1998}$ & $1 \times 10^{-2}$ & $\mathrm{Ru}^{103}$ & $10^{-25}$ & \\
\hline $\mathrm{Ca}^{45}$ & $10^{-5}$ & $5 \times 10^{-4}$ & $R_{u} 106$ & 0.1 & 0.1 \\
\hline $\mathrm{Cr}^{51}$ & $10^{-39}$ & 0.5 & 131 & $10^{-136}$ & $3 \times 10^{-5}$ \\
\hline $\mathrm{Fe}^{55}$ & 9.3 & & $\mathrm{Cs}^{137}$ & 81 & $1.5 \times 10^{-3}$ \\
\hline $\mathrm{Fe}^{59}$ & $10^{-22}$ & $4 \times 10^{-3}$ & $\mathrm{Ce}^{141}$ & $10^{-32}$ & \\
\hline $\mathrm{Co}^{60}$ & 26.5 & $2 \times 10^{-2}$ & $\mathrm{Ce}^{144}$ & $1.3 \times 10^{-2}$ & $4 \times 10^{-2}$ \\
\hline $\mathrm{Cu}^{64}$ & $10^{-2026}$ & $1 \times 10^{-4}$ & $\mathrm{Pm}^{147}$ & 6.2 & 1 \\
\hline
\end{tabular}

MPC for mixtures of isotopes of unknown composition is $10^{-7} \mu \mathrm{c} / \mathrm{ml}$.

beyond the life of the steel drum. On the other hand, experiments designed to test the effect of hydrostatic pressure on disposal containers, indicated that voids in concrete may, at depths of a few hundred to a thousand meters, permit implosion of the steel drum and fracture of the concrete, thereby bringing about premature release of contaminant to the sea.

The tests of canisters which have been performed have been concerned with disposal into at least 1000 fathoms of water where pressures in excess of 3000 pounds per square inch will be encountered, whereas we are concerned here with water depths up to approximately 30 fathoms where pressure less than 100 pounds per square inch will be encountered. Although there is some doubt as to whether presently used containers remain intact after disposal to the sea bottom, proper design and testing can provide the necessary information. 
After release to the sea, following intentional introduction of liquid wastes or after rupture of a canister, the concentration of the waste will be continually diminished by dilution brought about by the natural turbulent mixing processes that occur in the sea, and the mixture of waste and sea water will be moved from the disposal site by ocean currents. An evaluation of the extent of dilution together with processes that might combine to return the wastes to man are discussed below.

\section{TRANSPORT AND DISPERSION}

The movement of a contaminant from the disposal area and its dilution with sea water will be controlled by circulation in and adjacent to the disposal site and the natural turbulent mixing processes in the sea. Obviously, the bottom water circulation in the immediate area of the disposal site will control the initial movements of the soluble and finely divided waste as it diffuses from the ruptured canister.

\section{Movement of Bottom Sediment}

The mechanisms and patterns of bottom sediment transportation on continental shelves are poorly understood. The general circulation of the near-bottom water does not wholly control the movements of bottom sediments since tides, waves, storm surges and tsunami impose controls which may in fact outweigh in importance the average circulation of near-bottom water. Important in such considerations is the recent conclusion independently proposed by several groups studying the sediment budget of North Sea beaches that up to half the sediments contributed to certain advancing beaches has been derived off shore from the floor of the North Sea. The possibility thus exists that detrital waste may reach adjacent beaches in undesirable quantities.

The base of effective wave action has been variously estimated at 30 feet to 900 feet. The discovery of strong scour on seamounts and on the Mid-Atlantic Ridge to depths of 2000 fathoms has been interpreted as evidence that there is no effective wave base. On the other hand, most geologists believe that really intense wave action is limited to the upper 30 to 100 feet of the ocean. Because movement of bottom materials can be quite independent of the average water circulation since it partly depends on wave action and not wholly on water transport, it must be considered separately. Before extensive inshore dumping is commenced, it would seem desirable to dump harmless trace material and observe from what distances appreciable material reaches the adjacent beaches.

\section{Near-bottom Water Circulation}

Sub-surface circulation has not been studied with sufficient detail to provide a basis for reliable prediction of the direction and speed of transport at all seasons of the year in any location that might be chosen for a disposal area. Evaluation of bottom circulation must be inferred from observations of salinity and temperature distributions, and 
measurements of surface drift, the latter largely from drift bottle experiments. A few direct measurements of bottom currents have been made from lightships.

Our knowledge of bottom water circulation along the Atlantic Coast may best be summarized by the following four items:

a. There is an area extending from south of Nantucket Shoals westward to the offing of New York from about 30 fathoms to 50 fathoms which appears to be somewhat isolated from the general circulation pattern. Following the vernal development of the pycnocline this lens of water retains its winter characteristics, remains in the same geographic location and does not become modified until the autumn overturn. There appears to be restricted interchange of some of the water seaward with slope water. In other words this portion of the continental shelf below the pycnocline tends to stagnate for about six months of the year.

b. Observation posts on lightships reveal a mid-summer inshore movement of bottom water along the coast from Virginia to New Jersey and subsequent upwelling, presumably due to off shore movement of surface waters due to wind shear. How far inshore from the lightships this intrusion occurs we do not know.

The observations also suggest a downwelling during the coldest parts of the winter when waters next to the coast chill to low temperatures, and subsequent offshore movement when resulting densities reach below those of the adjacent offshore waters. This mechanism appears to occur in areas farthest from river mouths where the salinity inshore is highest. This phenomenon has been observed at Nantucket Shoals where the bottom off shore movement was deduced to reach 2 miles per day $(4 \mathrm{~cm} / \mathrm{sec})$ and south of Long Island where chilled coastal water contributed to the offshore lens of cold water.

c. The pycnocline develops only very weakly in the coastal areas south of Cape Hatteras, allowing greater vertical mixing here than to the north where the pyncnocline is better developed.

d. Bottom flow in the areas seaward from the mouths of estuaries can be expected to be shoreward, with intensification of shoreward movement during seasons in which the land drainage into the estuary is at a maximum.

Surface circulation.

The movement of surface waters, summarized below, will be important to the distribution of contaminant after diffusion and transport from the bottom have brought the contaminant into the surface waters.

a. At the seaward end of all coastal estuaries the surface flow can be expected to be seaward with a tendency toward southerly flow along the coast adjacent to the estuary. 
b. In general the circulation in the Gulf of Maine comprises a counterclockwise eddy. The drift along the Maine-Massachusetts coast is southerly, on the order of 2-6 miles per day $(4-13 \mathrm{~cm} / \mathrm{s} \mathrm{ec})$. The southerly part of the circulation, in Massachusetts Bay, is comprised of two drifts, one counterclockwise around Cape Cod Bay, and one across the mouth of Massachusetts Bay toward the outer coast of Cape Cod and thence southerly. The drift from Georges Bank is generally west during the spring and summer but more offshore and perhaps even easterly during the autumn and winter.

c. South of Massachusetts, Rhode Island, and New York the coastal drift tends to be westerly, 3-5 miles per day, $(6-11 \mathrm{~cm} / \mathrm{sec})$ and from the offing of New Jersey southward to Cape Hatteras the set is southerly with speeds varying from 3-15 miles per day $(6-32 \mathrm{~cm} / \mathrm{sec})$.

d. From Cape Hatteras to Georgia the surface non-tidal drift tends northeasterly at speeds of 0.2 to 12 miles per day, (.4 to 26 $\mathrm{cm} / \mathrm{sec}$ ) with the highest concentrations of drift bottle strandings on the southern side of the Capes. From Georgia to Daytona Beach the set appears to be southerly and from Daytona Beach south the drift appears to be northerly (unpublished data).

e. Redfield and Walford (11) noted that ". . wastes likely to be transported to beaches in the surface layers should be carried at least 10 miles to sea if contamination of beaches is to be avoided." The percentage frequency of strandings of drift bottles from areas off the U.S. coast, figure 2, indicates the variation in what may be construed as onshore or offshore areas of drift. The contours extend farthest offshore in the Gulf of Maine and south of Nantucket. They bend in towards the mouths of the Hudson River, Delaware and Chesapeake Bays. On the other hand, on either side of the mouths of these estuaries the frequency of returns is high. Note also the high percentage of returns from bottles dropped from Georgia southward.

\section{Diffusion Processes}

In addition to the gross transportation of contaminants by permanent and semi-permanent ocean currents, the mechanism by which a contaminant will move from the bottom if current velocities are zero at the water-bottom interface is obviously important. This mechanism is diffusion controlled. Similarly, once the contaminant is contained in water its dispersion and subsequent dilution will also be controlled by turbulent diffusion processes. So far as can be discovered, there are no direct measurements of diffusion-controlled processes within the areas of interest that can be used to evaluate the relative importance of these mechanisms to the movement of the contaminants. It is possible, however, to treat the problem theoretically, by imposing a number of simplifying assumptions which give a result that is not an accurate description of the diffusion process, but does give limiting values of the concentration of contaminant in the sea. Reid (12) has examined several cases in which the following assumptions were made: 


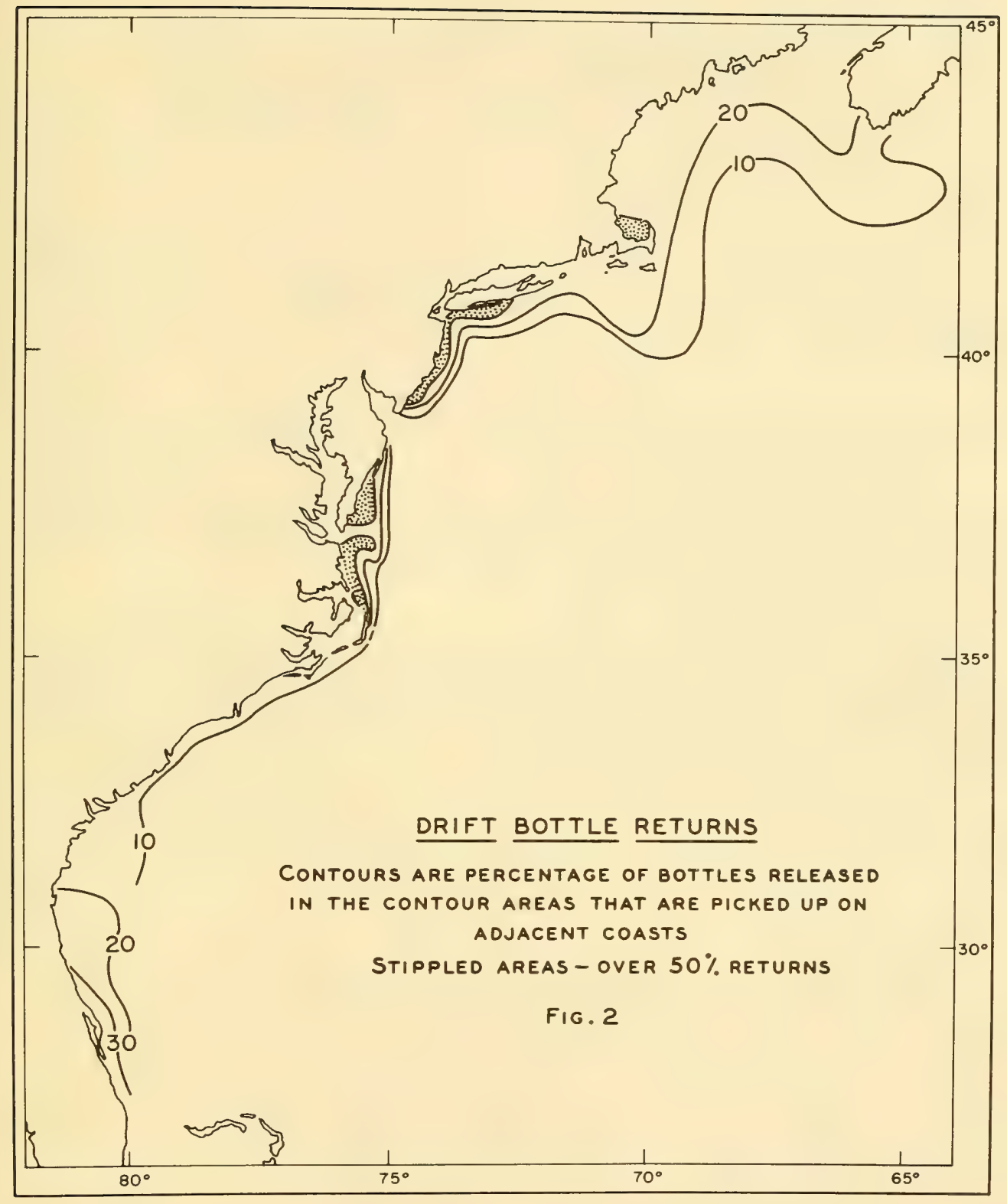


a. The radioactivity in sea water is not depleted by adsorption by the bottom solids, or by the uptake of marine organisms.

b. Natural radioactive decay has been neglected.

c. The diffusion process is considered to be Fickian.

d. The ocean is considered to be of uniform depth.

The assumption of Fickian diffusion implies that the dispersion of a contaminant at distances from the source is much slower than is known to occur. The assumptions of no adsorption by bottom solids and marine organisms, and no radioactive decay obviously lead to an overestimate of the concentration of contaminant.

Several cases are considered, corresponding to possible conditions of release of the contaminant to the sea. These are summarized below.

Sustained Gross Source. This case is analogous to the continued release of a contaminant, at a known rate, as from the end of a pipe, or the diffusion of contaminant from ruptured canisters, under a steady state condition of supply and rupturing of canisters.

Considering a bottom disposal area of dimension $L \times L$, over which the water depth is $\mathrm{D}$, with a uniform current of speed U parallel to the coast, and a diffusivity coefficient $K$, the maximum concentration of contaminant $C_{m}$ along the axis of the current at distance $x$ from the source, (when $x$ is large compared with $L$ ) for a rate of supply $Q$, is given by:

(1)

$$
C_{m}=\frac{Q}{2 D \sqrt{2 \pi K U x}}
$$

The maximum concentration at various distances as evaluated from equation (1) are listed in Table IV for the following conditions:

$$
\begin{aligned}
& \text { Rate of supply } Q=100 \text { curies per year }(274 \mathrm{mc} / \text { day) } \\
& \text { Depth of water } D=30 \text { meters ( } 90 \text { feet) } \\
& \text { Diffusivity coefficient } K=1 \mathrm{~cm}^{2} / \mathrm{sec} \\
& \text { Current velocity } U-10 \mathrm{~cm} / \mathrm{sec} \text { (approx. } 5 \mathrm{n} . \mathrm{mi} / \text { day) }
\end{aligned}
$$


TABLE IV

\section{MAXIMUM CONCENTRATION $C_{m}$ AT DISTANCES X FROM SUSTAINED GROSS SOURCE WITH RATE OF SUPPLY 100 CURIES PER YEAR}

\begin{tabular}{|c|c|}
\hline$x(\mathrm{Km})$ & $\mathrm{C}_{\mathrm{m}}(\mu \mathrm{c} / \mathrm{ml})$ \\
\hline 1 & $2 \times 10^{-7}$ \\
\hline 2 & $1.6 \times 10^{-7}$ \\
\hline 4 & $1 \times 10^{-7}$ \\
\hline 10 & $7 \times 10^{-8}$ \\
\hline 20 & $5 \times 10^{-8}$ \\
\hline 40 & $3 \times 10^{-8}$ \\
\hline 100 & $2 \times 10^{-8}$ \\
\hline
\end{tabular}

It has been estimated that because of the assumptions under which equation 1 was developed, the concentrations listed in Table IV are certainly high by at least a factor of 10, and probably by a factor of 100 .

Instantaneous Source. This case is analogous to the sudden rupturing of a cubical canister on the bottom under the assumption that all of the contaminant is then free. Assuming no current to aid in dispersal, the reduction in concentration at the canister due to diffusion processes is given by:

$$
\mathrm{C}=\frac{\mathrm{C}_{\mathrm{o}}}{4} \frac{\mathrm{V}}{(\pi \mathrm{Kt})^{3 / 2}}
$$

where, $\mathrm{C}=$ the concentration at time $\mathrm{t}$

$\mathrm{C}_{\mathrm{O}}=$ initial concentration

$\mathrm{V}=$ volume of canister

$\mathrm{K}$ = diffusivity coefficient

The ratio of the interim concentration to initial concentration as a function of time for the specific case of $\mathrm{K}=1 \mathrm{~cm} 2 / \mathrm{sec}, \mathrm{V}=190$ liters (volume approx. 50 gallons) is given in figure 3. It is seen that 0.01 curies contained initially in approximately 50 gallons, $C_{0}=54 \mu \mathrm{c} / \mathrm{kg}$, would be reduced to approximately $2 \mu \mathrm{c} / \mathrm{kg}$ in 1 hour and to $0.06 \mu \mathrm{c} / \mathrm{kg}$ in 10 hours. 


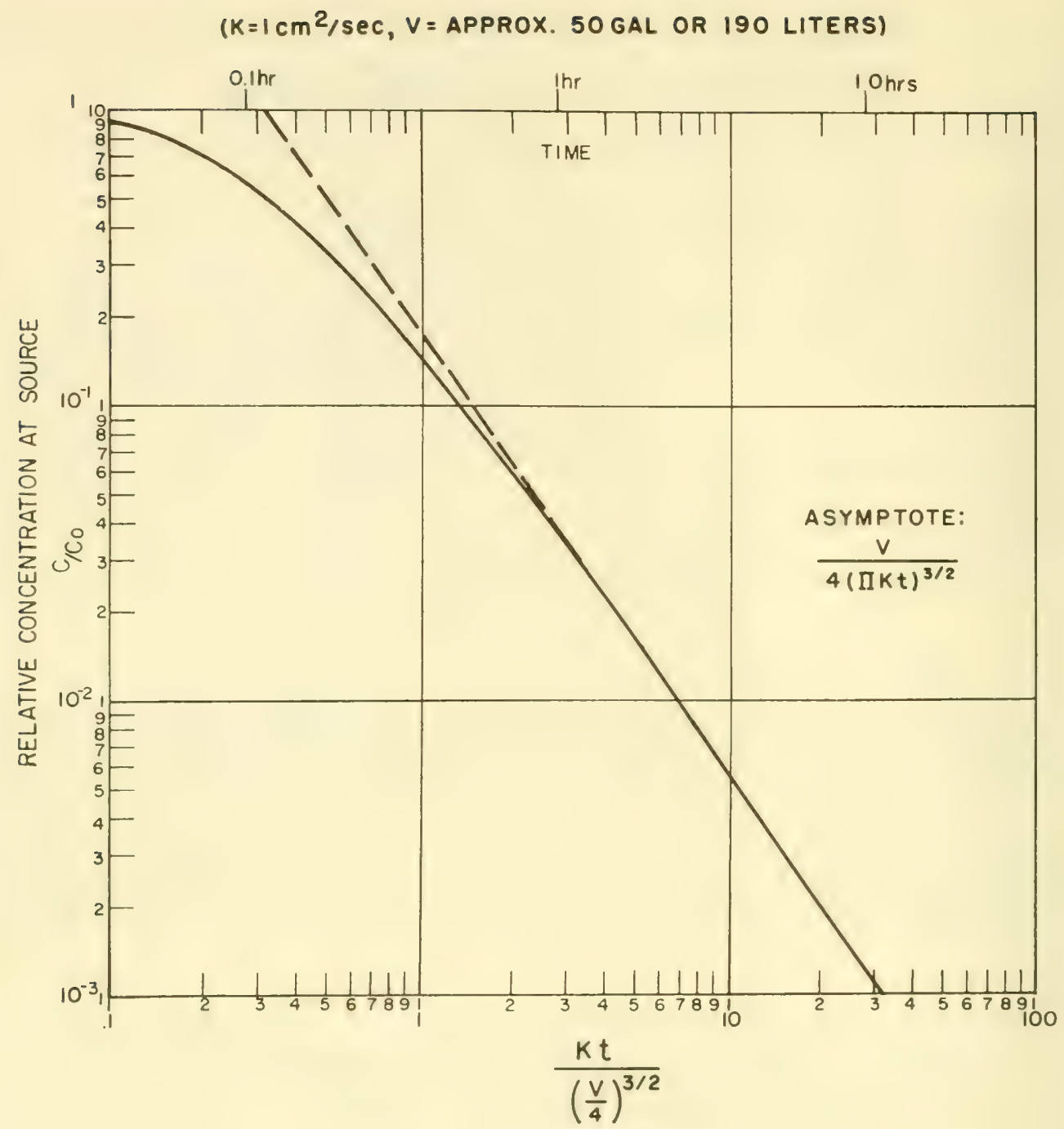

FIGURE 3

DIFFUSIVE DECAY OF CONCENTRATION AT SOURCE SOURCE ON BOTTOM $D=\infty$ 
In addition to the time-concentration relationship, it is of interest to know the effect of distance from disposal site on the concentration for point sources. The maximum relative concentration (C/Co) as a function of distance from the site is shown for three cases in figure 4. Curve 1 assumes infinite depth of water, curve 2 assumes that the ratio of water depth to canister size is 100 , and curve 3 assumes infinite depth and that all of the waste is not immediately available but diffuses from the ruptured canister at a uniform rate under the conditions that the diffusion coefficient through the ruptured canister is $10^{-6}$ that of the diffusivity in the water. The latter case is discussed below.

Continuous Source at Uniform Leaching Rate. This case treats the situation analogous to the diffusion of contaminant from the concrete that remains after the steel casing has corroded and affords no further containment. In the development of this case, it has been assumed that the amount of contaminant diffusing through the permeable concrete walls is directly proportional to the surface area of the container, directly proportional to the difference in concentrations inside and immediately outside the container, and inversely proportional to the thickness

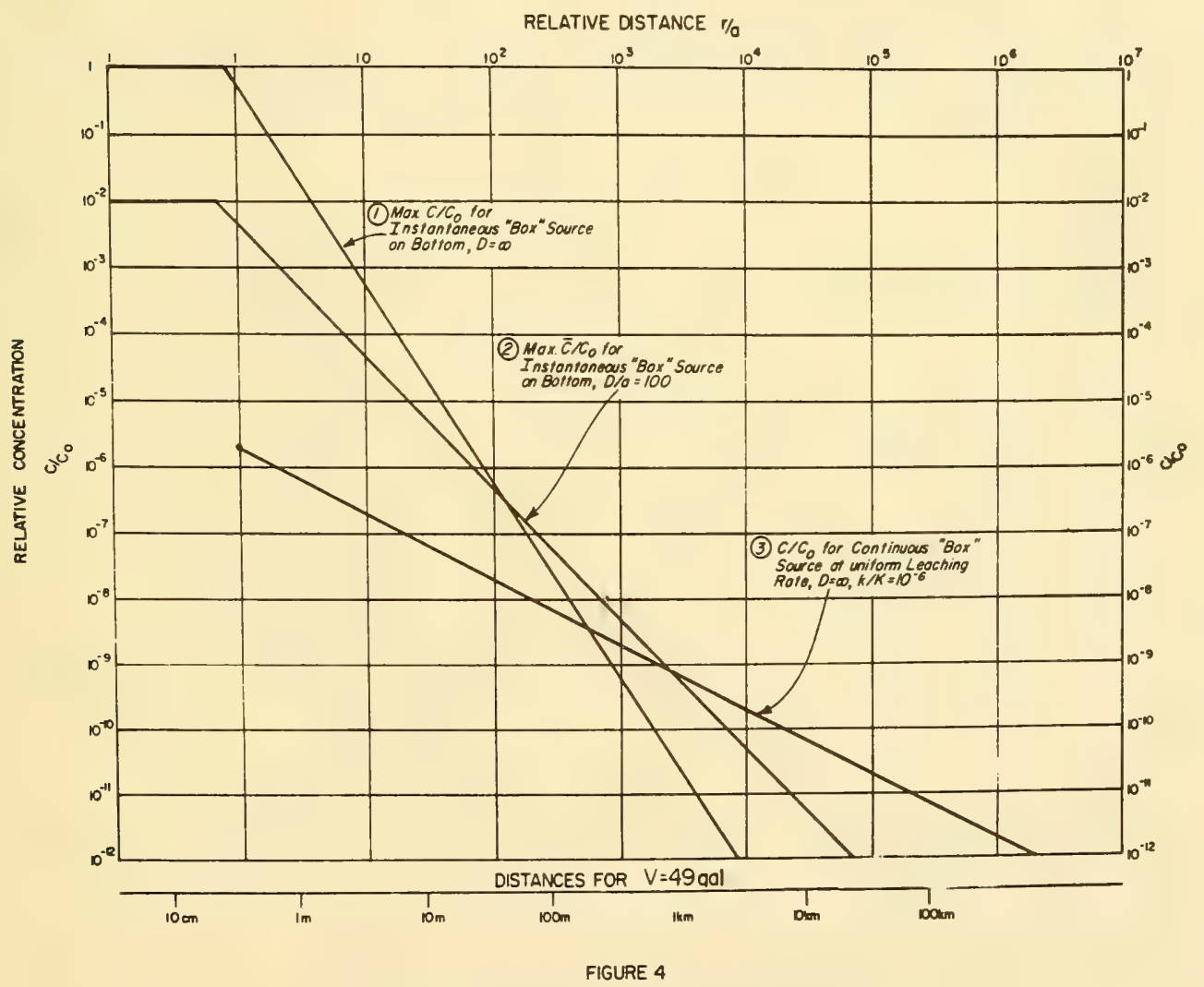

RELATIVE CONCENTRATION VERSUS DISTANCE FROM SOURCE 
of the walls. The effective diffusion coefficient through the walls is taken as the molecular diffusivity times the porosity of the walls, and in numerical computations is assumed to be $10^{-6} \mathrm{~cm}^{2} / \mathrm{sec}$. The relative concentration-distance relationship is shown by curve 3 in figure 4.

Reid further shows that under the condition of continual supply of canisters to a disposal area and given the assumptions noted above, the time required to reach a steady state between rate of disposal and leaching rate will be fourteen years. That is, only after fourteen years will the quantity of contaminant released to the water be equal to the rate at which contaminant is deposited on the bottom in canisters. If the life of the steel canister is ten years, as noted previously, the time to reach steady state would then be an additional ten years, or a total of twentyfour years.

\section{SORPTION AND EXCHANGE}

Coastal waters in general contain relatively large quantities of suspended solids. The solids are in part living organic materials, the plankton, and in part suspended, inanimate, organic and inorganic solids. A portion of the latter are materials being carried seaward by land drainage sources and will ultimately become bottom deposits. Another portion, that usually near the ocean bottom, is periodically brought into suspension by tidal action and storm-generated turbulence. All these materials including the "bottom" have a measurable tendency to adsorb (remove from solution) and to hold substances dissolved in the water.

The sorptive properties of these solids are extremely variable. Neglecting for the moment uptake by marine organisms, the quantity of material adsorbed by a given weight of suspended inorganic solids will depend upon the mineral composition of the solids, the composition of the solution in which the solids are suspended, and the past history of the solids. All of these factors are nearly impossible to evaluate quantitatively for conditions likely to be found in nature.

Although impossible to evaluate quantitatively, it seems certain that sorption processes will play a major role in controlling the dispersal of radioactive wastes once they are free of the canister. This conclusion is based upon the results of a few laboratory studies, in addition to qualitative field observations made during bomb tests and by the British at their disposal operation in the Irish Sea. The details are given in NAS-NRC publication 551, chapter $6(5)$, and are summarized below:

1. Partial removal of mixed fission products from solution was achieved by centrifugal separation of naturally occurring solids from a contaminated solution.

2. The sorption of phosphate, iodide, iron III, strontium, sulphate, and copper II onto Chesapeake Bay sediments has been measured under a variety of environmental conditions. With the exception of iodide, appreciable removal from solution by the solids was observed under all conditions. 
3. Sorption onto selected clay minerals has been studied and is recommended as a means of solution decontamination, under certain conditions.

4. The differences in composition between marine sediments and the solids carried to sea by rivers is attributed to exchange and sorption reactions between the solids and dissolved substances during sedimentation.

5. The sediments in the area around the end of the discharge line from the British Atomic Energy Authority processing plant at Windscale on the shore of the Irish Sea, show a relatively large accumulation of radioactive substances.

Although some of this information is quantitative it cannot be applied directly to the dispersal problem we are considering. Nevertheless, since radioactive waste components and naturally occurring suspended and deposited solids generally exhibit exchange and sorption reactions; and since the disposal canisters will be partially or perhaps completely buried in bottom deposits during the time the waste components are escaping from them, it seems inevitable that the se reactions will have a major influence in controlling the rate of dispersal and ultimate distribution of the wastes.

These sorption and exchange reactions appear to us to be a safety factor (an exception is noted below) in disposal problems. So far as uptake by permanent bottom deposits are concerned the effect is that of achieving additional containment time, thus providing for greater radioactive decay than would be achieved by containment only in the canister.

There is at least one situation in which sorption onto bottom deposits may represent the development of a possibly hazardous situation. This is the situation in which bottom areas adjacent to a disposal site are the source of marine food products such as oysters, clams, mussels, etc. In this case accumulation of wastes on the bottom would provide for a greater level of contamination of the food product than would occur in the absence of sorption and exchange with the bottom. Our recommendation of a complete survey of a proposed inshore disposal area prior to the start of disposal operation will help preclude the development of such a hazard.

Because we are unable to make a quantitative estimate of the magnitude of uptake on suspended and deposited solids, we have neglected this factor in our evaluation of the quantities of wastes likely to be found in the water and in marine food products for various rates of disposal of radioactive wastes. We believe that by neglecting this factor our recommendations concerning disposal rates include a safety factor of at least 10 , and possibly more. 


\section{PERMISSIBLE CONCENTRATIONS OF RADIOISOTOPES IN SEA WATER AND UPTAKE BY MARINE ORGANISMS}

We have noted previously that we consider the return of radioactive wastes to man in the form of contaminated marine food products to be the most serious potential hazard that might be created by the use of near-shore areas as disposal sites.

The ability of aquatic organisms to concentrate certain substances within themselves at higher levels than exists in their environment is well known. From earlier studies involving the concentration of the major nutrients, carbon, nitrogen, and phosphorus by phytoplankton and the aquatic plants, and the passage of these materials from plants to animals through successive prey - predator steps, we have a generalized picture of the nutrient cycles in which many kinds of aquatic organisms are involved. Following these early studies with the major nutrients, several of the trace metals that appear as minor but essential nutrients were studied, and recently the behavior of radioisotopes of several biologically important elements has become known. This information was discussed in detail in NAS-NRC publication 551, chapters 7,8 , and 9 (5). Using this information, plus the results of studies completed since 1957, we can estimate the quantities of many radionuclides that will be contained within a variety of aquatic organisms when their environment contains stated concentration of the same nuclides.

We have combined this information regarding the probable quantities of radionuclides in commercially landed fish with figures for maximum permissible concentrations in drinking water, to obtain the quantity of radionuclides that will be returned to man in marine food products, as follows:

1. The MPC values (3) are based upon acquiring a permissible body burden of a given radionuclide, below which no observable biological damage will occur, by drinking approximately 15,000 milliliters (15 liters) of water per week, at MPC levels, for 30 years. Thus, the MPC values permit the calculation of a permissible weekly intake for each of the nuclides listed. For example, the MPC value for $\mathrm{Sr} 90$ is $8 \times 10^{-7} \mu \mathrm{c} / \mathrm{ml}$. We calculate the permissible weekly intake of $\mathrm{Sr} 90$ to be $1.2 \times 10^{-2} \mu \mathrm{c}$.

2. Using the permissible weekly intake as calculated above and figures for the quantity of fish eaten per person per week, it should be possible to compute the maximum permissible concentration of any nuclide in fish.

In contrast to the drinking of water, man's seafood eating habits are extremely variable. According to Taylor (13) the average U.S. consumption of seafood is approximately 10 pounds per year. Comparable figures for other countries are France, 20; Great Britain, 48; Japan, 111 pounds per year. The average consumption of seafood, however, has little significance since large proportions of the population live far from the sea coast and eat little or no fish or other marine products. 
A man would have to eat approximately four pounds of fish weekly in order to match the average U.S. protein consumption. It has seemed to us reasonable to take a value approaching this as the extreme case of an individual subsisting almost entirely on fish as the source of protein in his diet, and have used $1.5 \mathrm{~kg}$ ( 3.3 pounds) per week in further computations. For example, for Sr 90 , using $1.2 \times 10^{-2} \mu \mathrm{c}$, computed above, as the maximum permissible weekly intake of nuclide and $1.5 \mathrm{~kg}$ as the weekly consumption of fish, we compute $8 \times 10^{-3} \mu \mathrm{c} / \mathrm{kg}$ as the maximum permissible concentration of $\mathrm{Sr} 90$ in fish.

3. Next, having the maximum permissible concentration of a nuclide in fish and the concentration factor achieved by fish for the nuclide we compute the maximum permissible concentration for the nuclide in sea water. Again using $\mathrm{Sr} 90$ as an example, the maximum permissible concentration in fish of $8 \times 10^{-3} \mu \mathrm{c} / \mathrm{kg}$, combines with a concentration factor of 10 , assuming the density of fish to be 1.0 , to give a maximum permissible concentration in sea water of $8 \times 10^{-4} \mu \mathrm{c} /$ liter or $8 \times 10^{-7} \mu \mathrm{c} / \mathrm{ml}$, which by coincidence is identical with the MPC value in drinking water.

4. These computations are summarized by the relationship:

$M P C \times D=P S C \times f \times F$

where:

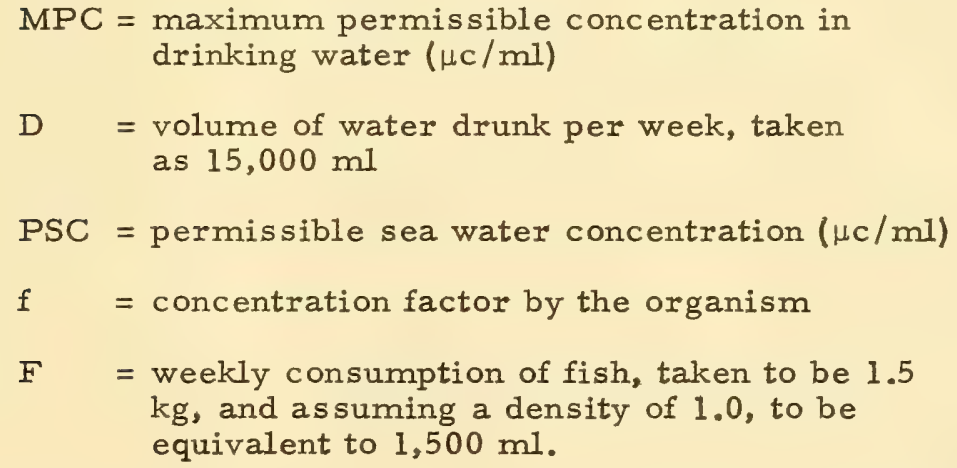

Computations, outlined above, have been made for a number of radionuclides, including the major isotopes shipped from ORNL, as well as several of the more hazardous fusion product elements. These computations are summarized in Table V.

\section{POSSIBLE CONFLICTS WITH OTHER INTERESTS}

\section{Commercial Fisheries}

Many areas along the Atlantic and Gulf coasts of the United States have well developed, active fisheries. The disposal of radioactive wastes in these areas might be objectionable, not only because of the possibility 


\section{TABLE $V$}

\section{SUMMARY OF PERMISSIBLE CONCENTRATION OF SELECTED RADIONUCLIDES IN DRINKING WATER; EDIBLE MARINE PRODUCTS; AND SEA WATER}

1.

$\operatorname{MPC}(\mu \mathrm{c} / \mathrm{cc})$
2.

Maximum weekly
3. dose $(\mu \mathrm{c})$
4.

Concentration
5.

\begin{tabular}{|c|c|c|c|c|c|}
\hline & $\operatorname{MPC}(\mu \mathrm{c} / \mathrm{cc})$ & dose $(\mu c)$ & $\operatorname{PFC}(\mu, c / g m)$ & factor & $\operatorname{PSC}(\mu \mathrm{c} / \mathrm{ml})$ \\
\hline H3 & 0.2 & 3.000 & 2 & $-\cdot$ & - \\
\hline C 14 & $3 \times 10^{-3}$ & 45 & $3 \times 10^{-2}$ & -- & -- \\
\hline No 24 & $8 \times 10^{-3}$ & 120 & $8 \times 10^{-2}$ & 0.5 & $1.6 \times 10^{-1}$ \\
\hline P 32 & $2 \times 10^{-4}$ & 3 & $2 \times 10^{-3}$ & $4 \times 10^{4}$ & $5 \times 10^{-8}$ \\
\hline S 35 & $5 \times 10^{-3}$ & 75 & $5 \times 10^{-2}$ & 5 & $1 \times 10^{-2}$ \\
\hline K 42 & $1 \times 10^{-2}$ & 150 & $1 \times 10^{-1}$ & 10 & $1 \times 10^{-2}$ \\
\hline $\mathrm{Ca} 45$ & $5 \times 10^{-4}$ & 7.5 & $5 \times 10^{-3}$ & 10 & $5 \times 10^{-4}$ \\
\hline Cr 51 & $5 \times 10^{-2}$ & 750 & $5 \times 10^{-1}$ & -- & -. \\
\hline $\mathrm{Fe} 59$ & $4 \times 10^{-3}$ & 60 & $4 \times 10^{-2}$ & $10^{4}$ & $4 \times 10^{-6}$ \\
\hline Co 60 & $2 \times 10^{-2}$ & 300 & $2 \times 10^{-1}$ & $10^{4 \star}$ & $2 \times 10^{-5}$ \\
\hline Cu 64 & $8 \times 10^{-2}$ & 1200 & $8 \times 10^{-1}$ & $5 \times 10^{3}$ & $1.6 \times 10^{-4}$ \\
\hline $\mathrm{Zn} 65$ & $6 \times 10^{-2}$ & 900 & $6 \times 10^{-1}$ & $5 \times 10^{3}$ & $1.2 \times 10^{-4}$ \\
\hline Sr 90 & $8 \times 10^{-7}$ & 0.012 & $8 \times 10^{-6}$ & 10 & $8 \times 10^{-7}$ \\
\hline 1131 & $3 \times 10^{-5}$ & 0.45 & $3 \times 10^{-4}$ & 100 & $3 \times 10^{-6}$ \\
\hline Cs 137 & $1.5 \times 10^{-3}$ & 22.5 & $1.5 \times 10^{-2}$ & $50^{\star *}$ & $3 \times 10^{-4}$ \\
\hline Ir 192 & $9 \times 10^{-4}$ & 13.5 & $9 \times 10^{-3}$ & -- & -- \\
\hline
\end{tabular}

1. Handbook 52 values (3).

2. From MPC and weekly ingestion rate of 15 liters of water.

3. Permissible fish concentration. From maximum weekly dose, and weekly ingestion rate of 1.5 $\mathrm{kg}$ of fish.

4. The concentration factors for the soft tissues of vertebrates or invertebrates, whichever is higher, from Revelle and Schaeffer (5). In all coses, except P 32, figures are for invertebrates; vertebrates are lower by a factor of one half to one tenth.

*Maximum factor for plankton species. Ketchum and Bowen (in press).

$\star \star$ Data for soft tissues of oysters. Chipman (unpublished). 
of contamination of the fish, with the development of a potential hazard to consumers, but also because the accumulation of disposal containers on the bottom might create a hazard to fishing equipment, especially to trawl gear that would become damaged or possibly lost if dragged over heavy concrete disposal containers. Furthermore, if radioactive disposal areas are to be closed to fishing, as they undoubtedly should be, it is in the interest of the best uses of our marine resources that disposal areas be placed where little or no fishing now occurs.

In some areas the fishing intensity is well defined. This is the case in the coastal area northward from Long Island and including the Gulf of Maine. Most coastal estuaries have well developed fisheries. Thus, such areas as Delaware Bay, Chesapeake Bay, Albemarle Sound and Pamlico Sound are undesirable locations for disposal sites not only because of the shoreward transport in the bays and the restricted circulation in the sounds, but also because of possible conflict with the fisheries.

The region east and slightly south of Long Island between the 30 and 50 fathom contours, in which fishing vessels are unlikely to be found, coincides with the region noted previously to be characterized by "summer stagnation". The lack of fishing effort in this area suggests it as a possible location for disposal sites. However, the restricted circulation through the region for about six months of the year suggests that during the times of "stagnation" an accumulation of wastes might occur in the area to such an extent that adjoining areas might be adversely affected once circulation is restored following the fall turn-over. At best, regions of this kind should be used as disposal sites only after a careful study of the year round exchange of water with adjoining areas.

Unfortunately, detailed studies have not been made over the entire Atlantic and Gulf coasts. However, it seems likely that appropriate information can be obtained, for any proposed site, from state and local fisheries groups.

In general the trend is toward the development of fisheries in deeper and deeper water. At present very little fishing is done beyond 100 fathoms. However, experimental fishing has been carried on out to 1000 fathoms, and indications are that with an increased demand for fish and with the development of the proper fishing gear, these relatively deep areas can support a considerable fishing effort.

\section{Submarine Cables.}

The disposal of packaged radioactive wastes in areas through which submarine cables pass will be objectionable from two points of view. First, there is a possibility of damage to the cable should a disposal container fall directly on it during disposal operations. Second, during cable maintenance and repair it is common practice to drag grappling equipment across the ocean bottom to locate the cable and to bring it to the surface. An accumulation of disposal containers on the bottom in such a location not only could interfere with the grappling 
operation but might result in the premature rupture of a disposal container with possible exposure of personnel to measurable radiation.

The location of submarine cables along the east coast of the United States is shown in figures 5 and 6. Proposed disposal sites have been chosen in areas not crossed by cables.

\section{MAXIMUM RATE OF DISPOSAL}

The maximum rate of disposal should be such that permissible sea water concentrations are not continuously exceeded. Several problems arise when this criterion is applied to practical disposal operations. Firstly, disposal is a discontinuous process and even though activity will probably leach slowly from disposal containers for quite some time following rupture of the canister, it is highly unlikely that the rate of supply of activity to the water will be constant. How then should we average such a process? Secondly, the flux of contaminant from a disposal container will decrease as the amount of contaminant in the container decreases, producing an effect similar to that noted above. Thirdly, only a small fraction of the total volume of coastal waters will actually pass directly over a disposal area, although a much larger fraction of the total volume will be available for dilution. Most of these problems involve the averaging of concentrations that will be above and below permissible sea water concentrations for unknown lengths of time.

We have solved this problem by using the boundaries of the dis posal area as the spatial limit beyond which the concentration of contaminant should never exceed the permissible sea water concentration. Using the relationship shown in equation $1,(p .20)$ and assuming that a disposal canister will not contain more than 2 curies (approximately the limit set by ICC regulations), we find that for a disposal area 2 miles in diameter (the size of several suggested disposal areas), a disposal rate of between 200 and 300 curies of strontium 90 per year will keep the concentration below the permissible sea water concentration at the disposal area boundary. We have chosen 250 curies of strontium 90 or its equivalent.

\section{PRE-USE SURVEY AND MONITORING}

A precise evaluation of the quantity of radioactive substances that will be returned to man as the result of a stated rate of disposal into any one of the selected areas cannot be given. The recommended maximum rate of disposal (250 curies of $\mathrm{Sr} 90$, or its equivalent) will, even under the most unfavorable combination of circumstances, result in concentrations of contaminant outside the disposal areas below permissible levels.

In order to obtain essential information not now available that will permit full utilization of the disposal areas without limiting other uses of coastal waters, the committee recommends, (1) a survey of any area prior to disposal operations, and (2) the monitoring of an area subsequent to the beginning of disposal operations. 


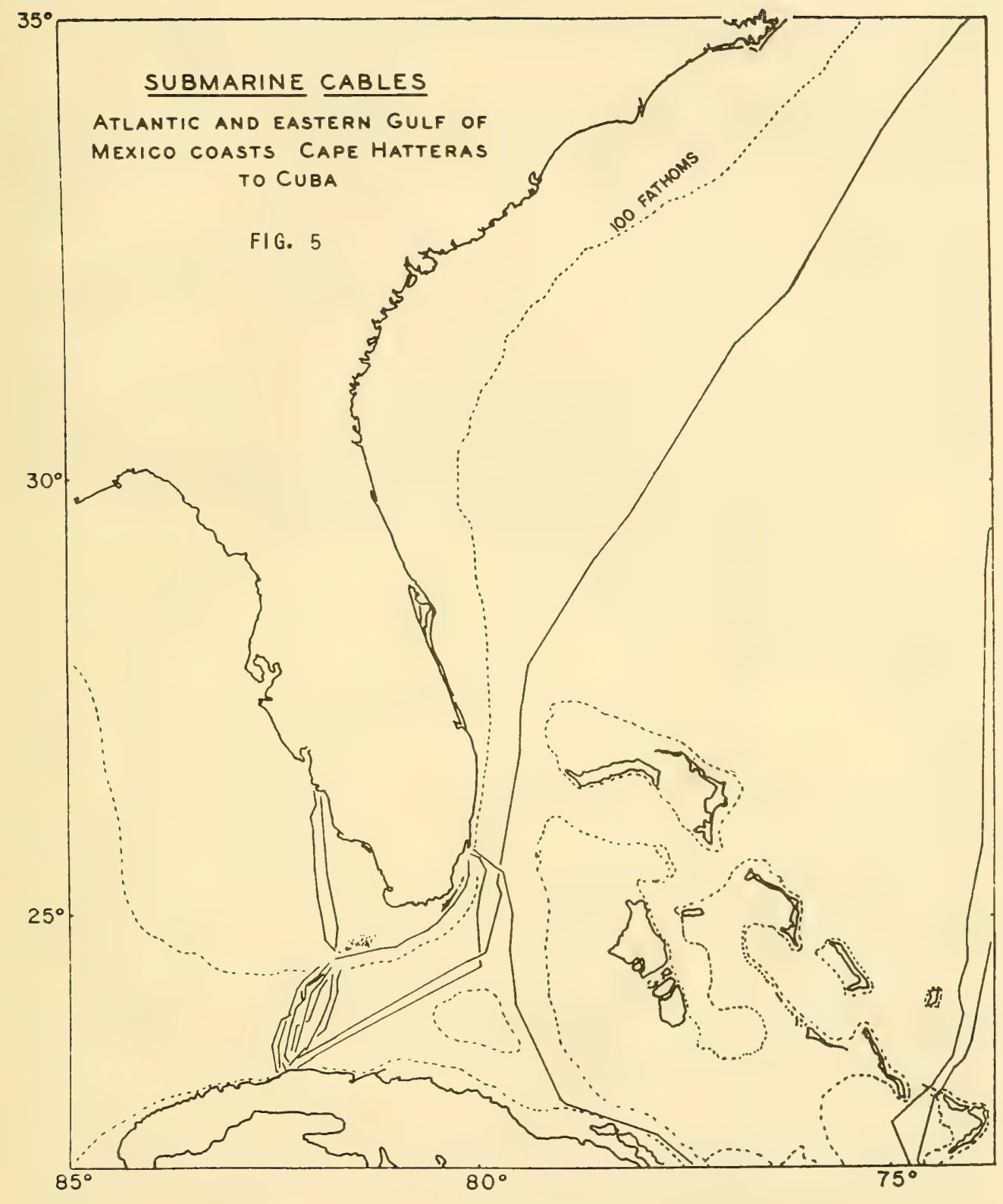




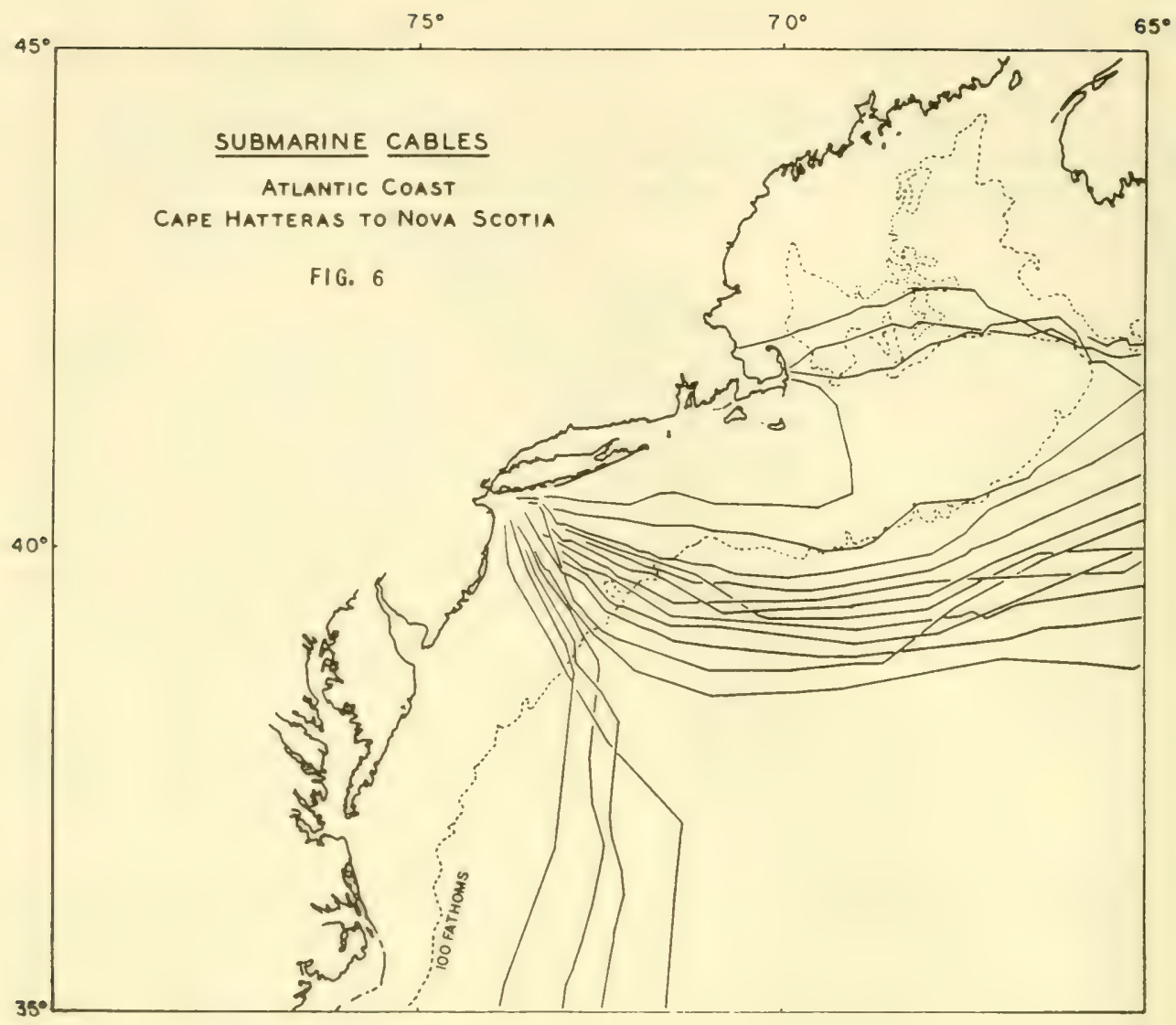

The pre-use survey should be designed to provide the following information:

(1) Detailed circulation, including seasonal variations, in and adjacent to the disposal area, conducted so as to permit an evaluation of the dilution afforded by turbulent mixing within the area and transport from the area by ocean currents.

(2) Measurement of the seasonal variations in the kind and quantities of aquatic organisms within and adjacent to a disposal area, especially organisms attached to or living in the bottom. These may concentrate or move components of the wastes and so act first as a containment element and second as a convenient indicator, during subsequent monitoring operations, of the spread of activity throughout the disposal area and of possible "leaking" out of the disposal area. 
(3) Analysis of bottom sediments for mineral types, especially for components known to have high absorptive capacities, e.g. the clays.

(4) Analysis of bottom organisms and bottom deposits for existing radioactivity. This will be low prior to disposal, being primarily from natural activities and fall-out. The analysis should be conducted so as to distinguish between naturally occurring $\mathrm{K} 40$ and $\mathrm{Cl} 4$ and manmade isotopes, especially $\operatorname{Sr} 90$.

(5) The existence of commercial and sports fishing activities within and adjacent to the selected area, determined by reference to U. S. Fish and Wildlife records and state and local authorities.

Monitoring of a disposal area at intervals following the start of disposal operations will be essential to the safe and efficient use of an area. Monitoring procedures should include the collection of both bottom living organisms and bottom sediments, and analysis of each for radioactivity. The frequency of sampling and the methods of analysis should be such that estimates of the following can be made:

(1) the containment provided by disposal canisters;

(2) the distribution of waste components in the biota and the bottom sediments;

(3) the existence of a steady state involving disposal rate and distribution within the disposal area.

\section{DISPOSAL AREAS}

Suggested disposal areas are shown in figure 7, and their exact location listed in Table VI.

Inasmuch as there are a number of disposal areas presently available, designated as "explosives dumping area" or "dumping ground (by permit only)", some of which have been used heretofore for the disposal of low level radioactive wastes as well as for certain toxic chemical wastes, we have included these areas in the list of suggested sites. We have numbered the sites 1 to 12 . Alternative sites have been marked with the subscript a or $\underline{b}$ indicating that they might be used as secondary disposal areas but are more inconvenient to reach than the primary disposal area.

Most of the dumping areas are large: $10 \times 10$ miles, 10 miles in diameter, or the like. We have indicated the centers of these areas, with one exception. Additional sites listed might be two miles in diameter centered on the positions given. Sites presently listed in "A special report on disposal of radioactivity into Atlantic Ocean waters-past, present, and predicted", U.S.A.E.C. Division of Reactor Development, November 1957, are marked with an *. 


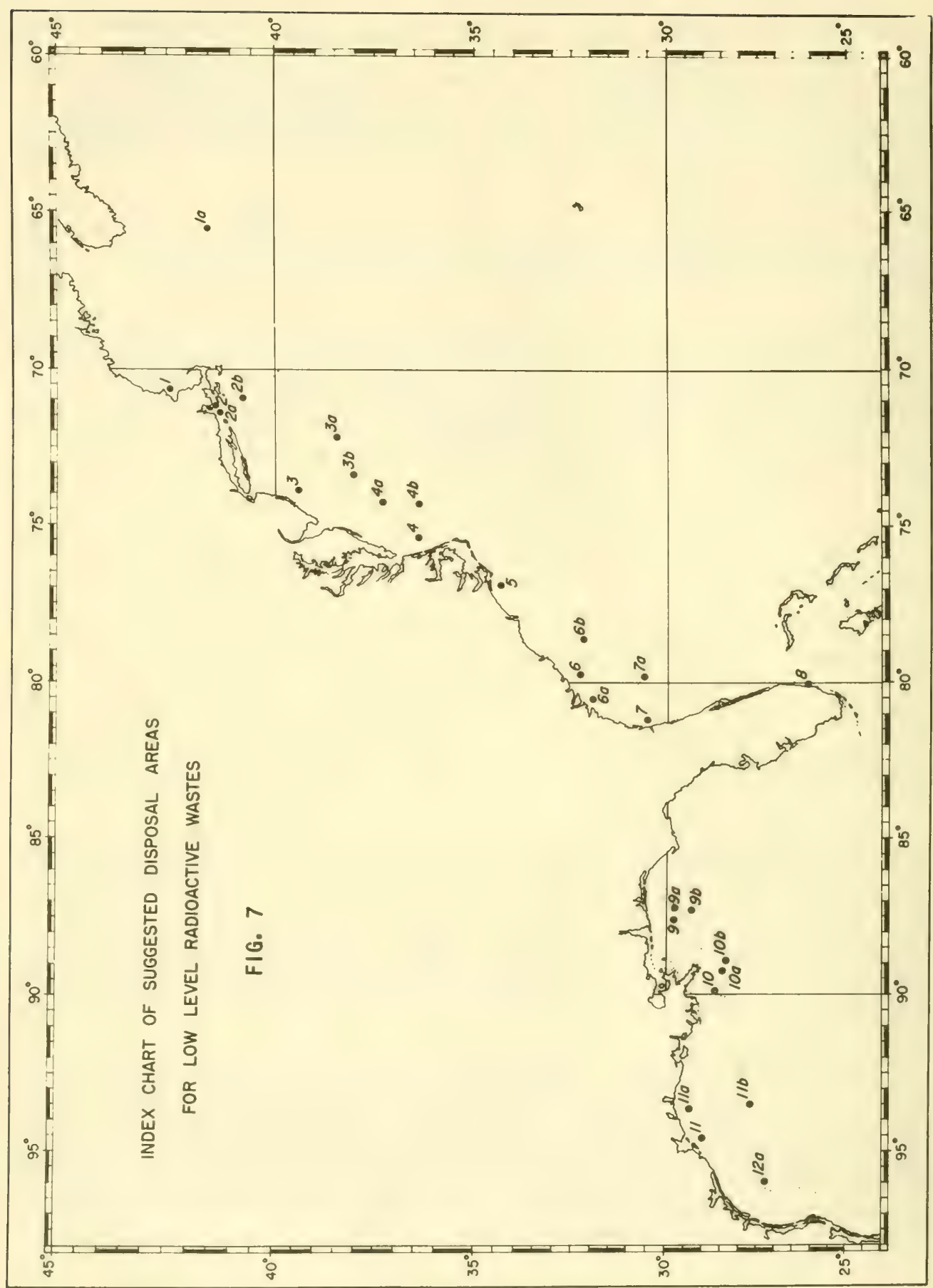


TABLE VI

\section{LOCATION OF SUGGESTED DISPOSAL AREAS}

To serve Boston, Massachusetts:

1* $\quad 42^{\circ} 25.5^{\prime} \mathrm{N} 70^{\circ} 35^{\prime} \mathrm{W} 312 \mathrm{ft} .2$ miles in diameter, marked "Foul Area, Explosives" presently used by Crossroads Marine Disposal Company, 22 miles from Boston, Chart 1207.

la* $41^{\circ} 33^{\prime} \mathrm{N} 65^{\circ} 30^{\prime} \mathrm{W} 6000 \mathrm{ft}$. "Explosives Dumping Area" $10 \times 10$ miles square, Chart 71.

To serve Providence, Rhode Island:

$241^{\circ} 19.7^{\prime} \mathrm{N} 71^{\circ} 063^{\prime} \mathrm{W} 48-90 \mathrm{ft}$. Rocky ledge known as "Browns Ledge" 10 miles from Sakonnet, Rhode Island, Chart 1210.

2a $\quad 41^{\circ} 14^{\prime} \mathrm{N} 71^{\circ} 25^{\prime} \mathrm{W}$ 110-126 ft. 2 miles in diameter marked "Danger, Unexploded Depth Charges, May 1952", 10 miles from Pt. Judith, Rhode Island, Chart 1210.

2b $40^{\circ} 45^{\prime} \mathrm{N} 70^{\circ} 52^{\prime} \mathrm{W} 202 \mathrm{ft}$. "Explosives Dumping Area, Disused". 10 x 10 miles square, 45 miles from Sakonnet Point, Rhode Island, Chart 71, 1108.

To serve New York - Delaware Bay:

$3 \quad 39^{\circ} 26.7^{\prime} \mathrm{N} 73^{\circ} 56.6^{\prime} \mathrm{W} 80 \mathrm{ft}$. "Danger Area" 2 miles in diameter 22.5 miles from Atlantic City, Chart 1217.

$3 a^{*} \quad 38^{\circ} 30^{\prime} \mathrm{N} 72^{\circ} 06^{\prime} \mathrm{W} 7200-9000 \mathrm{ft}$. "Explosives Dumping Area" $10 \times 10$ miles square, 118 miles $098^{\circ} \mathrm{T}$ from Five Fathom Bank Lightship, Chart 1000.

3b $\quad 38^{\circ} 05^{\prime} \mathrm{N} 73^{\circ} 24^{\prime} \mathrm{W} 5580-6360 \mathrm{ft}$. "Explosives Dumping Area" $10 \times 10$ miles square, 70 miles $127^{\circ} \mathrm{T}$ from Five Fathom Bank Lightship, Chart 1109.

To serve Norfolk, Virginia:

$4 \quad 36^{\circ} 49^{\prime} \mathrm{N} 75^{\circ} 27^{\prime} \mathrm{W}$ Wreck 9-1/4 in $66 \mathrm{ft} .37$ miles from Little Creek, Chart 1109.

4a $\quad 37^{\circ} 19^{\prime} \mathrm{N} 74^{\circ} 15^{\prime} \mathrm{W} 3000-4800 \mathrm{ft}$. "Explosives Dumping Area" $10 \times 10$ miles square, 73 miles $074^{\circ} \mathrm{T}$ from Chesapeake Lightship, Chart 1109.

$4 b^{*} \quad 36^{\circ} 30^{\prime} \mathrm{N} 74^{\circ} 18^{\prime} \mathrm{W} 6000-7500 \mathrm{ft}$. "Explosives Dumping Area" $10 \times 10$ miles square, 74 miles $113^{\circ} \mathrm{T}$ from Chesapeake Lightship, Chart 1109.

To serve Morehead City - Beaufort, North Carolina:

$534^{\circ} 26^{\prime} \mathrm{N} 76^{\circ} 54^{\prime} \mathrm{W} 77-81 \mathrm{ft}$. A "tear up" area according to "Report of North Carolina Shrimp Survey", Institute of Fisheries Research University North Carolina, January 1951. 22 miles from Morehead City, Chart 1234.

To serve Savannah area:

$32^{\circ} 20^{\prime} \mathrm{N} 79^{\circ} 55^{\prime} \mathrm{W} 60 \mathrm{ft}$. "Dumping Ground (by permit only)" 8.5 miles diameter, 20 miles $136^{\circ} \mathrm{T}$ from mouth of North Edisto R., Chart 1111. 
TABLE VI-Continued

$6 a$

$6 \mathrm{~b}$ $32^{\circ} 15^{\prime} \mathrm{N} 78^{\circ} 40^{\prime} \mathrm{W} 120 \mathrm{ft}$. "Explosives Dumping Area", 10 miles diameter, 70 miles from Charleston, South Carolina, Chart 1111.

To serve Jacksonville, Florida: $30^{\circ} 33^{\prime} \mathrm{N} 81^{\circ} 09.2$ 'W 67-70 ft. "Wreck, 42' Reported", 18 miles from Mayport, Chart 1243.

$7 a$ $30^{\circ} 37^{\prime} \mathrm{N} 79^{\circ} 53$ 'W $1800 \mathrm{ft}$. "Explosives Dumping Area, Disused", 83 miles from Mayport, Chart 1111.

To serve the Florida peninsula: $26^{\circ} 05.5^{\prime} \mathrm{N} 80^{\circ} 02.5^{\prime} \mathrm{W} 3600 \mathrm{ft} .2$ miles east of Port Everglades Sea Buoy, Chart 1248.

To serve Pensacola - Mobile Bay:

$29^{\circ} 48^{\prime} \mathrm{N} 87^{\circ} 33^{\prime} \mathrm{W} 138 \mathrm{ft}$. "Dumping Ground" 35 miles from Pensacola, Chart 1115.

$29^{\circ} 48^{\prime} \mathrm{N} 87^{\circ} 10^{\prime} \mathrm{W} 600 \mathrm{ft}$. Rough ground not suitable for trawling, 34 miles from Pensacola, Chart 1115.

96

$29^{\circ} 22^{\prime} \mathrm{N} 87^{\circ} 15^{\prime} \mathrm{W} 1800 \mathrm{ft}$. "Explosives Dumping Area, Disused", $10 \times 10$ miles square, Chart 1115 .

To serve New Orleans, Lovisiana:

$28^{\circ} 40^{\prime} \mathrm{N} 89^{\circ} 51^{\prime} \mathrm{W} 600 \mathrm{ft}$. Rough ground, not suitable for trawling, 26 miles from Southwest Pass, Chart 1116.

10a $28^{\circ} 30^{\prime} \mathrm{N} 89^{\circ} 10^{\prime} \mathrm{W} 1800 \mathrm{ft}$. "Explosives Dumping Area, Disused", 10 × 10 miles square, 30 miles from South Pass, Chart 1115.

$10 \mathrm{~b} 28^{\circ} 25^{\prime} \mathrm{N} 88^{\circ} 55^{\prime} \mathrm{W} 3600 \mathrm{ft}$. "Explosives Dumping Area", $10 \times 10$ miles square, 36 miles from South Pass, Chart 1115.

To serve Galveston, Texas:

$1129^{\circ} 00^{\prime} \mathrm{N} 94^{\circ} 35^{\prime} \mathrm{W} 54 \mathrm{ft}$. Southernmost corner of a $5.5 \times 11$ mile rectangle. "Dumping Ground (by permit only)" 21 miles from Galveston Entrance, Chart 1116.

lla $29^{\circ} 22^{\prime} \mathrm{N} 93^{\circ} 40^{\prime} \mathrm{W} 42 \mathrm{ft}$. Rectangular $4 \times 9$ miles "Dumping Ground (by permit only)" 19 miles from Sabine Pass, Chart 1116.

$11 \mathrm{~b} 27^{\circ} 40^{\prime} \mathrm{N} 93^{\circ} 30^{\prime} \mathrm{W} 1500 \mathrm{ft}$. "Explosives Dumping Area, Disused" $10 \times 10$ miles square, 100 miles $175^{\circ} \mathrm{T}$ from Galveston Entrance, Chart 1116.

To serve Corpus Christi, Texas:

12a $27^{\circ} 15^{\prime} \mathrm{N} 96^{\circ} 00^{\prime} \mathrm{W} 1500 \mathrm{ft}$. "Explosives Dumping Area, Disused", $10 \times 10$ miles square, 65 miles $122^{\circ} \mathrm{T}$ from Aransas Pass, Char 11117. 


\section{REFERENCES}

1. A special Report on Disposal of Radioactivity Into Atlantic Ocean Waters: Past, Present, and Predicted. Division of Reactor Development, U.S. Atomic Energy Commission, Washington 25, D.C. November 1957

2. Packaging of Contaminated (Radioactive) Scrap for Disposal. U.S. Atomic Erergy Commission. New York Operations Office, Health and Safety Laboratory, 70 Columbus Ave., New York 23, N.Y. (not dated)

3. Maximum Permissible Amounts of Radioisotopes in the Human Body and Maximum Permissible Concentrations in Air and Water. Handbook 52. U.S. Department of Commerce, National Bureau of Standards (1953)

4. Radioactive Waste Disposal in the Ocean. Handbook 58. U.S. Department of Commerce, National Bureau of Standards (1954)

5. The Effects of Atomic Radiation on Oceanography and Fisheries. National Academy of Sciences - National Research Council. Publication 551 (1957)

6. Report of a Meeting of United Kingdom and United States Scientists on Biological Effects of Radiation in Oceanography and Fisheries. National Academy of Sciences - National Research Council. (mimeograph) Oct. 31, 1956

7. Pathological Effects of Atomic Radiations. National Academy of Sciences National Research Council. Publication 452 (1956)

8. The Biological Effects of Atomic Radiation. Summary Reports. National Academy of Sciences - National Research Council (1956)

9. Looney, Wm. B. Effects of Radium in Man. Science, 127 No. 3299, p. 630 (1958)

10. Uhlig, H. H., Corrosion Handbook. John Wiley and Sons, pp. $383-390$ (1948)

11. Redfield, A. C. and L. A. Walford, A Study of the Disposal of Chemical Waste at Sea. Report of the Committee for Investigation of Waste Disposal. National Academy of Sciences - National Research Council. Publication 201 (1951)

12. Reid, R. O. An Analysis of Dispersion of Radioactivity from Local Sources on the Sea Bed. (Unpublished)

13. Taylor, Harden F. A Survey of Marine Fisheries of North Carolina. University of North Carolian Press. Chapel Hill, North Carolina 555 pp. (1951) 





\section{NATIONAL ACADEMY OF SCIENCES- NATIONAL RESEARCH COUNCIL}

The National Academy of Sciences-National Research Council is a private, nonprofit organization of scientists, dedicated to the furtherance of science and to its use for the general welfare.

The Academy itself was established in 1863 under a Congressional charter signed by President Lincoln. Empowered to provide for all activities appropriate to academies of science, it was also required by its charter to act as an adviser to the Federal Government in scientific matters. This provision accounts for the close ties that have always existed between the Academy and the Government, although the Academy is not a governmental agency.

The National Research Council was established by the Academy in 1916, at the request of President Wilson, to enable scientists generally to associate their efforts with those of the limited membership of the Academy in service to the nation, to society, and to science at home and abroad. Members of the National Research Council receive their appointments from the President of the Academy. They include representatives nominated by the major scientific and technical societies, representatives of the Federal Government, and a number of members-at-large. In addition, several thousand scientists and engineers take part in the activities of the Research Council through membership on its various boards and committees.

Receiving funds from both public and private sources, by contributions, grant, or contract, the Academy and its Research Council thus work to stimulate research and its applications, to survey the broad possibilities of science, to promote effective utilization of the scientific and technical resources of the country, to serve the Government, and to further the general interests of science. 


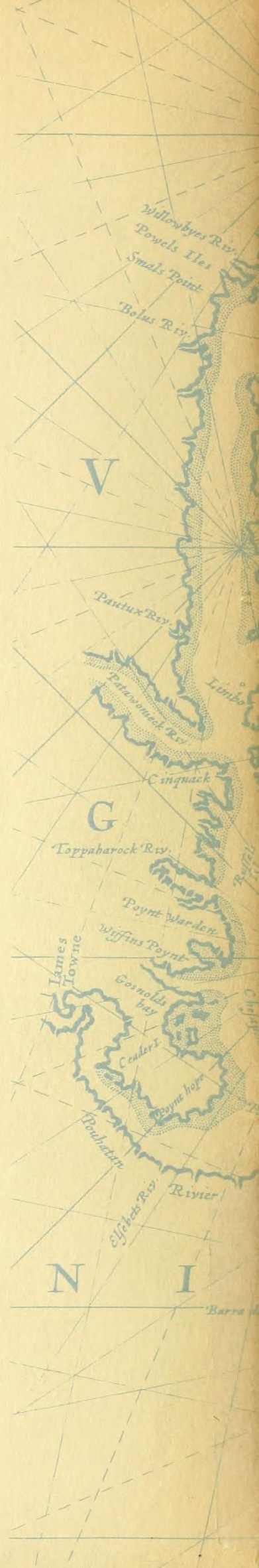

